\title{
The Importance of Patient-Specific Factors for Hepatic Drug Response and Toxicity
}

\author{
Volker M. Lauschke * and Magnus Ingelman-Sundberg \\ Section of Pharmacogenetics, Department of Physiology and Pharmacology, Karolinska Institutet, \\ SE-17177 Stockholm, Sweden; magnus.ingelman-sundberg@ki.se \\ * Correspondence: volker.lauschke@ki.se; Tel.: +46-8524-87711 \\ Academic Editor: William Chi-shing Cho \\ Received: 12 September 2016; Accepted: 27 September 2016; Published: 12 October 2016
}

\begin{abstract}
Responses to drugs and pharmacological treatments differ considerably between individuals. Importantly, only $50 \%-75 \%$ of patients have been shown to react adequately to pharmacological interventions, whereas the others experience either a lack of efficacy or suffer from adverse events. The liver is of central importance in the metabolism of most drugs. Because of this exposed status, hepatotoxicity is amongst the most common adverse drug reactions and hepatic liabilities are the most prevalent reason for the termination of development programs of novel drug candidates. In recent years, more and more factors were unveiled that shape hepatic drug responses and thus underlie the observed inter-individual variability. In this review, we provide a comprehensive overview of different principle mechanisms of drug hepatotoxicity and illustrate how patient-specific factors, such as genetic, physiological and environmental factors, can shape drug responses. Furthermore, we highlight other parameters, such as concomitantly prescribed medications or liver diseases and how they modulate drug toxicity, pharmacokinetics and dynamics. Finally, we discuss recent progress in the field of in vitro toxicity models and evaluate their utility in reflecting patient-specific factors to study inter-individual differences in drug response and toxicity, as this understanding is necessary to pave the way for a patient-adjusted medicine.
\end{abstract}

Keywords: drug-induced liver injury; hepatotoxicity; liver disease; pharmacogenetics

\section{Introduction}

Interindividual differences in response to pharmacological treatment are a major health concern. Importantly, only $50 \%-75 \%$ of patients have been shown to react adequately to common pharmacological interventions [1], whereas the others exhibit either a lack of efficacy or suffer from adverse drug reactions (ADRs). Genetic, physiological (e.g., gender, age, concomitant diseases, starvation and circadian rhythm) and environmental factors (e.g., co-administered medications, diet, smoking behavior and environmental pollutants) can impact on drug response with genetic variability accounting for around $20 \%-30 \%$ of these interindividual differences [2]. Today, the most important biomarkers for drug treatment relate to genetic variants in the somatic genome of cancer cells, predicting the effect of oncological compounds. In contrast, the most prominent classes of genes affecting drug pharmacokinetics encode enzymes and transporters, modulating absorption, distribution, metabolism and excretion (ADME).

The increasing understanding of genotype-drug response relationships led to a rise in numbers of drug labels with pharmacogenetic information issued by the US Food and Drug Administration (FDA) [3] and the European Medicines Agency (EMA) [4] targeted mainly at health care providers [5]. However, while thousands of biomarkers have been described in $>150,000$ scientific publications, currently only 24 genes are deemed pharmacogenetically actionable according to the Clinical Pharmacogenetics Implementation Consortium (CPIC; Table 1). Notably, this list only partly overlaps 
with the genetic testing requirements by American, European and Japanese regulatory agencies (Figure 1). Genotype-guided prescribing is only implemented for few drugs in the current clinical routine due to a variety of reasons, including: (i) problems in replicating identified associations, especially in the case of rare events; (ii) heterogeneous genetic nomenclature and non-standardized results reporting; as well as (iii) ethical; and (iv) regulatory considerations (reviewed in [6,7]). Therefore, overcoming these obstacles is of critical importance to further personalize pharmaceutical treatment, which could result in decreased morbidity and mortality for patients and a more efficient distribution of limited health-care resources.

Table 1. Overview of actionable pharmacogenetic gene-drug pairs. Data obtained from reference [8]. In total, 86 actionable gene drug pairs ( 24 unique genes and 73 unique drugs) are listed for which a change in prescribing is recommended based on genetic makeup of the patient (Actionable label and CPIC levels A or B).

\begin{tabular}{|c|c|c|}
\hline Gene & $\begin{array}{l}\text { Actionable } \\
\text { Pairs }\end{array}$ & Medications \\
\hline CYP2D6 & 20 & $\begin{array}{l}\text { Amitriptyline, codeine, fluvoxamine, nortriptyline, tramadol, aripiprazole, atomoxetine, } \\
\text { clomipramine, desipramine, doxepin, imipramine, protriptyline, trimipramine, vortioxetine, } \\
\text { iloperidone, perphenazine, dextromethorphan, eliglustat, pimozide, tetrabenazine }\end{array}$ \\
\hline$D P Y D$ & 2 & Capecitabine, fluorouracil \\
\hline$H L A-A$ & 1 & Carbamazepine \\
\hline CACNA1S & 4 & Desflurane, isoflurane, sevoflurane, succinylcholine \\
\hline RYR1 & 4 & Desflurane, isoflurane, sevoflurane, succinylcholine \\
\hline UGT1A1 & 2 & Irinotecan, belinostat \\
\hline$H L A-B$ & 4 & Phenytoin, oxcarbazepine, abacavir, carbamazepine \\
\hline TPMT & 3 & Thioguanine, azathioprine, mercaptopurine \\
\hline CYP2C19 & 8 & $\begin{array}{l}\text { Voriconazole, citalopram, dexlansoprazole, doxepin, esomeprazole, pantoprazole, carisoprodol, } \\
\text { clopidogrel }\end{array}$ \\
\hline CYP2C9 & 2 & Warfarin, celecoxib \\
\hline VKORC1 & 1 & Warfarin \\
\hline IFNL3 & 1 & Peginterferon $\alpha-2 b$ \\
\hline G6PD & 22 & $\begin{array}{l}\text { Chloroquine, chlorpropamide, dapsone, glibenclamide, glimepiride, glipizide, mafenide, methylene } \\
\text { blue, nalidixic acid, nitrofurantoin, norfloxacin, primaquine, probenecid, quinine, sodium nitrite, } \\
\text { sulfadiazine, sulfasalazine, erythromycin, sulfisoxazole, dabrafenib, pegloticase, rasburicase }\end{array}$ \\
\hline HPRT1 & 1 & Mycophenolic acid \\
\hline$A B L 2$ & 1 & Valproic acid \\
\hline$A S L$ & 1 & Valproic acid \\
\hline ASS1 & 1 & Valproic acid \\
\hline CPS1 & 1 & Valproic acid \\
\hline NAGS & 1 & Valproic acid \\
\hline OTC & 1 & Valproic acid \\
\hline POLG & 2 & Valproic acid, divalproex sodium \\
\hline CFTR & 1 & Ivacaftor \\
\hline NAGS & 1 & Carglumic acid \\
\hline GBA & 1 & Velaglucerase $\alpha$ \\
\hline
\end{tabular}

Recent research indicated that the vast majority of genetic germline variants with importance for drug pharmacokinetics are rare with minor allele frequencies (MAF) below 1\% [9-11]. These findings have important implications for the clinical application of pharmacogenomics, as they indicate that the phenotype of a patient regarding drug response cannot be reliably assessed by genotyping for few common variants and but rather that the entire genetic landscape in pharmacogenetic loci have to be analyzed comprehensively [12]. Besides genetic factors, inter-individual differences in drug response are caused by a multitude other parameters. In this review, we highlight the development of pharmacogenomic biomarkers and discuss concomitant liver diseases as factors that shape the 
response to administered medications. Lastly, we emphasize recent developments of cell models that are able to reflect these patient-specific factors and predict drug response and toxicity more accurately.

a

\begin{tabular}{|c|c|c|c|c|c|c|c|}
\hline & FDA & EMA & PMDA & & FDA & EMA & PMDA \\
\hline Abacavir & $\mathbf{x}$ & $\mathbf{X}$ & & Imatinib & $\mathrm{X}$ & $\mathbf{x}$ & $\mathbf{x}$ \\
\hline Afatinib & $\mathbf{x}$ & $\mathbf{x}$ & & Ivacaftor & $\mathbf{x}$ & $\mathbf{x}$ & \\
\hline Alectinib & $\mathbf{x}$ & & & Ivacaftor / lumacaftor & $\mathrm{x}$ & & \\
\hline Anastrozole & $\mathbf{x}$ & & & Lapatinib & $\mathbf{x}$ & $\mathbf{x}$ & $\mathbf{x}$ \\
\hline Arsenic trioxide & $\mathbf{x}$ & $\mathbf{x}$ & $\mathbf{x}$ & Letrozole & $\mathbf{x}$ & & \\
\hline Atazanavir & & $\bullet$ & & Lomitapide & & $\mathbf{x}$ & \\
\hline Azathioprine & $\bullet$ & & & Maraviroc & $\mathrm{x}$ & $\mathbf{x}$ & \\
\hline Bosutinib & $\mathbf{x}$ & $\mathbf{x}$ & & Mercaptopurine & $\bullet$ & & \\
\hline Brentuximab vedotin & & $\mathbf{x}$ & & Nilotinib & $\mathbf{x}$ & $\mathbf{x}$ & \\
\hline Carbamazepine & $\mathbf{x}$ & & & Norelgestromin & & $\mathbf{x}$ & \\
\hline Carglumic acid & $\mathrm{x}$ & $x$ & & Olaparib & $\mathbf{x}$ & & \\
\hline Ceritinib & $\mathbf{x}$ & $\mathbf{x}$ & & Osimertinib & $\mathbf{x}$ & & \\
\hline Cetuximab & $\mathbf{x}$ & $\mathbf{x}$ & $\mathbf{x}$ & Oxcarbazepine & $\bullet$ & & \\
\hline Cholic acid & $\mathbf{x}$ & & & Panitumumab & $\mathbf{x}$ & $\mathbf{x}$ & $\mathbf{x}$ \\
\hline Clopidogrel & $\bullet$ & & & Pegloticase & $\bullet$ & $\mathbf{x}$ & \\
\hline Cobimetinib & $\mathbf{x}$ & & & Pembrolizumab & $\mathbf{x}$ & & \\
\hline Crizotinib & $\mathbf{x}$ & $\mathbf{x}$ & $\mathbf{x}$ & Pertuzumab & $\mathbf{x}$ & $\mathbf{x}$ & \\
\hline Dabrafenib & $\mathbf{x}$ & $\mathbf{x}$ & & Phenylacetic acid & $\mathbf{x}$ & & \\
\hline Dasatinib & $\mathbf{x}$ & $\mathbf{x}$ & $\mathbf{x}$ & Pimozide & $\mathbf{x}$ & & \\
\hline Denileukin diftitox & $\mathbf{x}$ & & & Ponatinib & & $\mathbf{x}$ & \\
\hline Dextromethorphan & $\bullet$ & & & Rasburicase & $\mathbf{x}$ & & $\mathbf{x}$ \\
\hline Divalproex sodium & $\mathbf{x}$ & & & Rituximab & & $\mathbf{x}$ & \\
\hline Eliglustat & $\mathbf{x}$ & $\mathbf{x}$ & & Sodium benzoate & $\mathbf{x}$ & & \\
\hline Elosulfase alfa & $\mathbf{x}$ & & & Sodium phenylbutyrate & $\mathbf{x}$ & & \\
\hline Erlotinib & $\mathbf{x}$ & $\mathbf{x}$ & & Tetrabenazine & $\mathbf{x}$ & & \\
\hline Ethinyl estradiol & & $\mathbf{x}$ & & Trametinib & $\mathbf{x}$ & $\mathbf{x}$ & \\
\hline Everolimus & $\mathbf{x}$ & & & Trastuzumab & $\mathbf{x}$ & $\mathbf{x}$ & $\mathbf{x}$ \\
\hline Exemestane & $\mathbf{x}$ & & & Trastuzumab emtansine & $\mathbf{x}$ & $\mathbf{x}$ & \\
\hline Fulvestrant & $\mathbf{x}$ & $\mathbf{x}$ & $\mathbf{x}$ & Tretinoin & $\mathbf{x}$ & & \\
\hline Gefitinib & $\mathbf{x}$ & $\mathbf{x}$ & $\mathbf{x}$ & Vandetanib & & $\cdot$ & \\
\hline Ibritumomab & & $\mathbf{x}$ & & Velaglucerase alfa & $\mathbf{x}$ & $\mathbf{x}$ & \\
\hline Ibrutinib & $\mathbf{x}$ & $\mathbf{x}$ & & Vemurafenib & $\mathrm{x}$ & $\mathbf{x}$ & \\
\hline
\end{tabular}

b

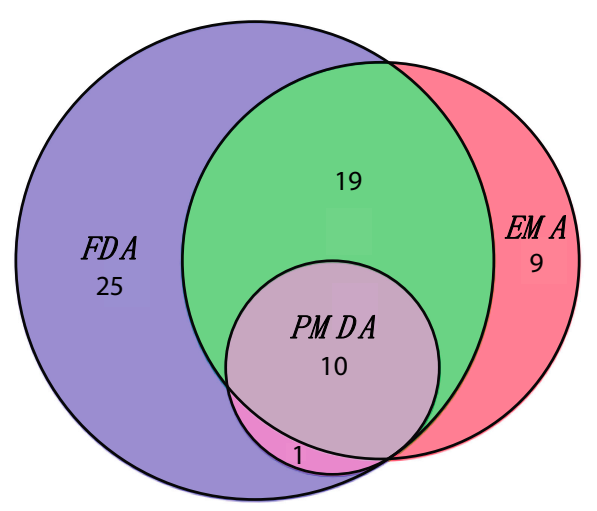

Figure 1. Drugs for which pharmacogenetic testing is recommended or required by major regulatory authorities: (a) Medications that require pharmacogenetic testing are indicated with " $\mathrm{X}$ ". If testing is only recommended, drugs are indicated with " $\bullet$ ". Requirements and recommendations by American (FDA), European (EMA) and Japanese (PMDA) regulatory authorities are shown. Note that only few medications (indicated in bold red) overlap with drugs for which prescribing action is recommended by the Clinical Pharmacogenetics Implementation Consortium (compare Table 1); (b) Venn diagram visualizing the overlap of drugs for which pharmacogenetic testing is required or recommended across FDA, EMA and PMDA. 


\section{Socioeconomical Aspects of Drug Hepatotoxicity}

Adverse reactions to medications account for approximately $6.5 \%$ of all hospital admissions and cause the death of $0.1 \%-0.2 \%$ of all hospitalized patients [13] with specific subpopulations being at even higher risk. In pediatric patients up to 39\% of ADR-related hospitalizations have been found to be life threatening or fatal [14]. Similarly, studies from Europe and the US indicate that $10 \%-30 \%$ of geriatric hospital admissions are drug-related $[15,16]$. ADRs have been estimated to cost around 3,000 US\$ per patient and amount to $5 \%-10 \%$ of annual hospital costs [17-19]. Combined costs for adverse medication-related events have been valued at 76.6 billion US $\$$ in the United States alone [20], yet societal costs might be even higher due to underreporting of ADRs incidences [21] and the neglect of indirect costs [22].

Besides effects on patients and health care systems, ADRs are important cost drivers for the pharmaceutical industry, causing the termination of a plethora of drugs during clinical development stages due to safety liabilities with the liver being the second most common organ after the cardiovascular system to be involved in safety failures [23]. One formidable example is the toxicity seen with fialuridine (FIAU). FIAU, a nucleoside analog for therapy of hepatitis B infections did not show toxicity in preclinical test systems, yet, in clinical trials, 7 of 15 participants developed severe hepatic dysfunctions, five of whom died [24]. Another example is the termination of fasiglifam (TAK-875) in clinical phase 3 trials due to hepatic safety concerns [25]. Furthermore, in the last years, $2 \%$ of all FDA-approved new medications were endowed with boxed warnings due to hepatic ADRs [26] and three drugs were withdrawn in post-marketing stages for hepatotoxicity (bromfenac, troglitazone and pemoline).

\section{Impact of Genetic Factors on Drug Metabolism}

In recent decades, many genetic factors, such as single nucleotide polymorphisms (SNPs) or copy number variations (CNVs) have been identified that influence drug response and susceptibility to toxicity and entail a modification of drug dosing (Table 2). Major genetic determinants of hepatotoxicity due to altered drug metabolism include DPYD polymorphisms and 5-fluorouracil toxicity in treatment of solid carcinomas [27], variants in TPMT and hematological toxicity of 6-mercaptopurines for treatment of leukemia and morbus Crohn [28,29], gene duplications of CYP2D6 and codeine toxicity [30] as well as the toxicity of the oncology compound irinotecan linked to indels in the UGT1A1 promoter (UGT1A1*28) [31]. Furthermore, genetic variants have been reproducibly and mechanistically linked to drug efficacy, as exemplified by the effect of CYP2C19 variants on voriconazole (CYP2C19*17) [32] and clopidogrel (CYP2C19*2) responsiveness [33].

One well-studied example of the impact of genetic polymorphisms on optimal dosing is illustrated by the impact of variants in CYP2C9 and VKORC1 on the metabolism of the anticoagulant warfarin that together account for approximately $30 \%$ of warfarin dose variability [34]. Furthermore, pharmacogenetic markers have been identified that affect drug efficacy, as evidenced by the relation of CYP2C19 genotypes on the metabolism of proton-pump inhibitors, such as omeprazole and pantoprazole, which in turn affects gastric $\mathrm{pH}$ and the healing rate of peptic ulcers as well as of Helicobacter pylori infections [35,36]. Another interesting pharmacogenetic association has been identified for the manifestation of myopathies mostly upon high dose treatment with simvastatin (80 mg daily) in which the presence of a single SNP in the transporter SLCO1B1 (rs4363657) can predict more than $60 \%$ of statin-induced myopathic ADRs [37]. For a more comprehensive overview of pharmacogenetic associations and their clinical translation, we refer to recent reviews that comprehensively summarized the progress in this field [38-40]. 
Table 2. Pharmacogenetic associations and their impact on dosing and prescribing. Dosing recommendations were gathered from the Clinical Pharmacogenetics Implementation Consortium (CPIC), the Royal Dutch Association for the Advancement of Pharmacy-Pharmacogenetics Working Group (DPWG) and the French National Pharmacogenetics Network together with the Group of Clinical Onco-pharmacology. DPD = dihydropyrimidine dehydrogenase; TPMT = thiopurine $S$-methyltransferase.

\begin{tabular}{|c|c|c|c|c|}
\hline Drug & Gene & $\begin{array}{c}\text { Activity Level } \\
\text { (Exemplary Genotypes) }\end{array}$ & $\begin{array}{l}\text { Pharmacological } \\
\text { Consequence }\end{array}$ & $\begin{array}{c}\text { Dosing } \\
\text { Recommendation }\end{array}$ \\
\hline \multirow{2}{*}{ Fluoropyrimidines } & \multirow{2}{*}{$D P Y D$} & $\begin{array}{l}\text { Intermediate DPD activity } \\
\qquad\left({ }^{*} 1 /{ }^{*} 2 \mathrm{~A},{ }^{*} 1 /{ }^{*} 13\right)\end{array}$ & \multirow{2}{*}{$\begin{array}{l}\text { Decreased fluoropyrimidine } \\
\text { catabolism and increased } \\
\text { levels toxic metabolites }\end{array}$} & $\begin{array}{c}\text { At least } 50 \% \text { initial } \\
\text { dose reduction }\end{array}$ \\
\hline & & $\begin{array}{c}\text { DPD deficiency } \\
\left({ }^{*} 2 \mathrm{~A} /{ }^{*} 2 \mathrm{~A},{ }^{*} 13 /{ }^{*} 13\right)\end{array}$ & & Select alternate drug \\
\hline \multirow{2}{*}{ Mercaptopurine } & \multirow{2}{*}{ TPMT } & $\begin{array}{c}\text { Intermediate TPMT activity } \\
\qquad \begin{array}{c}{ }^{*} 1 /{ }^{*} 2,{ }^{*} 1 /{ }^{*} 3 \mathrm{~A},{ }^{*} 1 /{ }^{*} 3 \mathrm{~B}, \\
\left.{ }^{*} 1 /{ }^{*} 3 \mathrm{C},{ }^{*} 1 /{ }^{*} 4\right)\end{array}\end{array}$ & \multirow{2}{*}{$\begin{array}{l}\text { Increased levels of cytotoxic } \\
\text { TGN metabolite }\end{array}$} & $\begin{array}{l}\text { Reduction to } 30 \%-70 \% \\
\text { of normal starting dose }\end{array}$ \\
\hline & & $\begin{array}{c}\text { TPMT deficiency }\left(* 3 \mathrm{~A} /{ }^{*} 3 \mathrm{~A},\right. \\
* 2 /{ }^{*} \mathrm{~A},{ }^{*} 3 \mathrm{C} /{ }^{*} \mathrm{~A},{ }^{*} \mathrm{C} /{ }^{*} 4, \\
\left.* 3 \mathrm{C} /{ }^{*} 2,{ }^{*} \mathrm{~A} /{ }^{*} 4\right)\end{array}$ & & $\begin{array}{c}\text { Drastic dose reduction to } \\
<10 \% \text { or consider } \\
\text { alternative therapy }\end{array}$ \\
\hline \multirow{3}{*}{ Codeine } & \multirow{3}{*}{$C Y P 2 D 6$} & $\begin{array}{l}\text { Ultrarapid metabolizer } \\
\left({ }^{*} 1 /{ }^{*} 1 \times N,{ }^{*} 1 /{ }^{*} 2 \times N\right)\end{array}$ & $\begin{array}{l}\text { Increased formation } \\
\text { of morphine }\end{array}$ & Select alternate drug \\
\hline & & $\begin{array}{l}\text { Intermediate metabolizer } \\
\qquad\left({ }^{*} 5 /{ }^{*} 41,{ }^{*} 4 /{ }^{*} 10\right)\end{array}$ & $\begin{array}{l}\text { Reduced formation } \\
\text { of morphine }\end{array}$ & $\begin{array}{l}\text { Dosage according to } \\
\text { label. If no response, } \\
\text { select alternate drug }\end{array}$ \\
\hline & & $\begin{array}{c}\text { Poor metabolizer } \\
\left(* 4 / * 4, * 4 / * 5, * 5 / * 5, * 4 /{ }^{*} 6\right)\end{array}$ & $\begin{array}{l}\text { Drastically reduced } \\
\text { formation of morphine }\end{array}$ & $\begin{array}{l}\text { Select alternate drug due } \\
\text { to lack of efficacy }\end{array}$ \\
\hline \multirow{2}{*}{ Irinotecan } & \multirow{2}{*}{ UGT1A1 } & $\begin{array}{l}\text { Intermediate UGT1A1 } \\
\text { activity }\left({ }^{*} 1 /{ }^{*} 28,{ }^{*} 1 /{ }^{*} 37\right)\end{array}$ & \multirow{2}{*}{$\begin{array}{l}\text { Reduced glucuronidation of } \\
\text { active metabolite SN-38 }\end{array}$} & $\begin{array}{c}\text { Standard dose } \\
\text { with rigorous } \\
\text { clinical surveillance }\end{array}$ \\
\hline & & $\begin{array}{l}\text { Strongly reduced UGT1A1 } \\
\text { activity }\left({ }^{*} 28 /{ }^{*} 28, * 37 / * 37\right)\end{array}$ & & $\begin{array}{l}\text { Dose reduction of } 30 \% \\
\text { for standard dose, no } \\
\text { dose intensification }\end{array}$ \\
\hline \multirow{3}{*}{ Clopidogrel } & \multirow{3}{*}{ CYP2C19 } & $\begin{array}{l}\text { Ultrarapid metabolizer } \\
\qquad\left({ }^{*} 1 /{ }^{*} 17,{ }^{*} 17 /{ }^{*} 17\right)\end{array}$ & $\begin{array}{c}\text { Increased formation of } \\
\text { active metabolite, decreased } \\
\text { platelet aggregation }\end{array}$ & Standard dose \\
\hline & & $\begin{array}{l}\text { Intermediate metabolizer } \\
\qquad\left({ }^{*} 1 /{ }^{*} 2,{ }^{*} 1 /{ }^{*} 3, * 2 /{ }^{*} 17\right)\end{array}$ & \multirow{2}{*}{$\begin{array}{c}\text { Reduced formation of active } \\
\text { metabolite, increased } \\
\text { platelet aggregation }\end{array}$} & Select alternate drug \\
\hline & & $\begin{array}{c}\text { Poor metabolizer } \\
(* 2 / * 2, * 3 / * 3, * 4 / * 4, * 5 / * 5, \\
* 6 / * 6, * 7 / * 7, * 8 / * 8)\end{array}$ & & Select alternate drug \\
\hline \multirow{3}{*}{ Omeprazole } & \multirow{3}{*}{ CYP2C19 } & $\begin{array}{l}\text { Ultrarapid metabolizer } \\
\qquad\left({ }^{*} 1 /{ }^{*} 17,{ }^{*} 17 /{ }^{*} 17\right)\end{array}$ & $\begin{array}{l}\text { Increased metabolic } \\
\text { inactivation to } \\
\text { 5-hydroxyomeprazole }\end{array}$ & $\begin{array}{l}\text { Increase dose } 2-3 \text {-fold } \\
\text { for } H \text {. pylori } \\
\text { eradication therapy }\end{array}$ \\
\hline & & $\begin{array}{l}\text { Intermediate metabolizer } \\
\qquad\left({ }^{*} 1 /{ }^{*} 2,{ }^{*} 1 /{ }^{*} 3,{ }^{*} 2 /{ }^{*} 17\right)\end{array}$ & \multirow{2}{*}{$\begin{array}{l}\text { Decreased metabolic } \\
\text { inactivation to } \\
\text { 5-hydroxyomeprazole }\end{array}$} & Standard dose \\
\hline & & $\begin{array}{c}\text { Poor metabolizer } \\
(* 2 / * 2, * 3 / * 3, * 4 / * 4, * 5 / * 5, \\
* 6 / * 6, * 7 / * 7, * 8 / * 8)\end{array}$ & & Standard dose \\
\hline \multirow[t]{2}{*}{ Simvastatin } & \multirow[t]{2}{*}{ SLCO1B1 } & $\begin{array}{c}\text { Intermediate SLCO1B1 } \\
\text { activity }\left({ }^{*} 1 \mathrm{a} /{ }^{*} 5,{ }^{*} 1 \mathrm{a} /{ }^{*} 15,\right. \\
{ }^{*} 1 \mathrm{a} /{ }^{*} 17,1 \mathrm{~b} /{ }^{*} 5, \\
\left.{ }^{*} 1 \mathrm{~b} /{ }^{*} 15,{ }^{*} 1 \mathrm{~b} /{ }^{*} 17\right)\end{array}$ & \multirow[t]{2}{*}{$\begin{array}{l}\text { Decreased hepatic } \\
\text { simvastatin uptake }\end{array}$} & \multirow{2}{*}{$\begin{array}{l}\text { High simvastatin doses } \\
(80 \mathrm{mg} / \text { day }) \text { not } \\
\text { recommended, consider } \\
\text { alternative statin }\end{array}$} \\
\hline & & $\begin{array}{c}\text { Strongly reduced } \\
\text { SLCO1B1 activity } \\
\left({ }^{*} /{ }^{*} 5,{ }^{*} 15 /{ }^{*} 15,{ }^{*} 17 /{ }^{*} 17\right)\end{array}$ & & \\
\hline
\end{tabular}

\section{The Importance of Rare Variant Alleles for Pharmacogenetics}

Strikingly, massive sequencing projects, such as the 1000 Genomes Project [41], the Exome Sequencing Project [42] and UK10K [43], revealed that the vast majority of genetic variants are rare with minor allele frequencies (MAFs) below $1 \%$. These rare variants are mostly population-specific and not represented in genome-wide association studies (GWAS) or targeted genotyping platforms [44,45]. 
In genetic loci with importance for drug absorption, distribution, metabolism and excretion (ADME), recent studies indicated that more than $90 \%$ of all variants were rare and not currently assessed by pharmacogenetic genotyping [9-11]. These data indicate that comprehensive sequencing-based approaches are necessary to descry the true genetic makeup in pharmacogenes. Furthermore, the combined phenotypic impact of these rare variants on drug response was estimated to overall exceed $30 \%$ [11]. Interestingly, elegant twin-studies on the pharmacokinetics of metropolol and torsemide revealed that while approximately $90 \%$ of the metabolic capacity of these drugs is genetically determined, known variants in the responsible pharmacogenes CYP2D6, CYP2C9, and SLCO1B1 only explained around $40 \%$ of the inter-individual differences [46]. These data corroborate the phenotypic importance of genetic variants beyond the well-characterized biomarkers, thus indicating that the assessment of rare genetic variability has to be incorporated into phenotypic predictions to be able to tailor treatment to the genotype of the individual patient within a precision medicine framework.

\section{Mechanisms of Drug-Induced Hepatotoxicity}

ADRs can be classified into reactions that are a direct consequence of the pharmacological action (e.g., hypotension with anti-hypertensive therapy and bleeding events with anti-coagulant treatment) of the drug and reactions in which toxicity and intended therapeutic mode of action differ (e.g., hepatic steatosis induced by the anti-epileptic drug valproic acid). The latter can be further subdivided into intrinsic ADRs with predictable rapid onset and typically dose-dependent severity (e.g., liver injury upon acetaminophen overdose) and idiosyncratic adverse reactions that occur with variable latency and where the risk to develop an ADR is not dependent on the dosing regimen but rather occurs only in few predisposed individuals (e.g., liver failure in patients treated with the anti-diabetic drug troglitazone). In the context of drug-induced liver injury (DILI), idiosyncratic reactions account for up to $10 \%$ of all DILI cases [47]. Chemically reactive metabolites (CRMs) are metabolic products that can result in mutagenicity or drug-drug interactions [48,49]. Furthermore, by covalently modifying proteins, CRMs of some compounds, including halothane [50,51] and diclofenac [52,53], can act as haptens and are recognized as a cause of idiosyncratic DILI reactions. Hence, efforts to reduce or eliminate such structural liabilities are routinely implemented in preclinical drug development pipelines. For an excellent critical overview of CRMs and the utility of structural alert analyses in preclinical development, we refer to the recent comprehensive review by Kalgutkar and Dalvie [54].

In the following section, we review key concepts in drug-induced hepatotoxicity. To this end, we focus on the role of mitochondria in cellular apoptosis and necrosis and highlight the role of the innate and adaptive immunity in DILI.

\subsection{Mitochondrial Perturbations}

Mitochondria are essential organelles that are involved in a variety of cellular processes. They generate the majority of cellular ATP in aerobic cells by oxidative phosphorylation, are the major site of fatty acid $\beta$-oxidation and oxidize pyruvate. Moreover, they are involved in apoptotic as well as necrotic cell death. Mitochondrial perturbations are a point of intersection of multiple different DILI mechanisms that can be as diverse as the direct toxicity seen with acetaminophen (APAP) [55] and immune-mediated liver injury due to tienilic acid [56] and are thus one of the major mechanisms underlying DILI [57]. Mitochondrial functionality can be impaired by directly inhibiting oxidative phosphorylation or fatty acid $\beta$-oxidation or by acting on mitochondrial DNA, transcripts or proteins (Figure 2). As a consequence of mitochondrial dysfunction, oxidative phosphorylation is uncoupled, ATP synthesis decreases and metabolic intermediates as well as pro-apoptotic molecules are released into the cytoplasm causing apoptosis or necrosis. 


\subsubsection{Inhibition of Mitochondrial Respiration}

The inhibition of mitochondrial respiration increases the formation of reactive oxygen species (ROS) by retaining electrons in upstream respiratory chain complexes. Furthermore, the oxidation of NADH to NAD+ is inhibited, which causes reduced capacity to oxidize pyruvate. As a result, pyruvate is primarily reduced to lactate and its buildup results in lactic acidosis. Furthermore, the paucity of NAD+ results in decreased $\beta$-oxidation and the accumulation of fatty acids causing steatosis [58]. Direct inhibition of the mitochondrial respiratory chain is caused e.g., by the non-nucleoside reverse-transcriptase inhibitor efavirenz, which is used for HIV treatment, and nefazodone, a triazolopyridine serotonin reuptake inhibitor. Efavirenz inhibits complex I of the respiratory chain in human hepatic cells in vitro, causing ATP depletion, compensatory upregulation of AMPK activity and increase in fatty acid uptake, leading to hepatic steatosis [59]. Nefazodone targets electron transport chain complexes I and IV, resulting in increased oxidative stress, glutathione depletion and hepatocellular necrosis [60]. Further examples of respiratory chain inhibition are the antiandrogen nilutamide, which inhibits NADH dehydrogenase (complex I) [61], and the antiarrythmic agent amiodarone, which causes inhibition of NADH dehydrogenase (complex I) and succinate dehydrogenase (complex II) in vitro [62]. In addition, we recently found the anticoagulant ximelagatran (Exanta) to decrease mitochondrial respiration after metabolic activation by mARC2 (also termed MOSC2; Figure 3) [63].

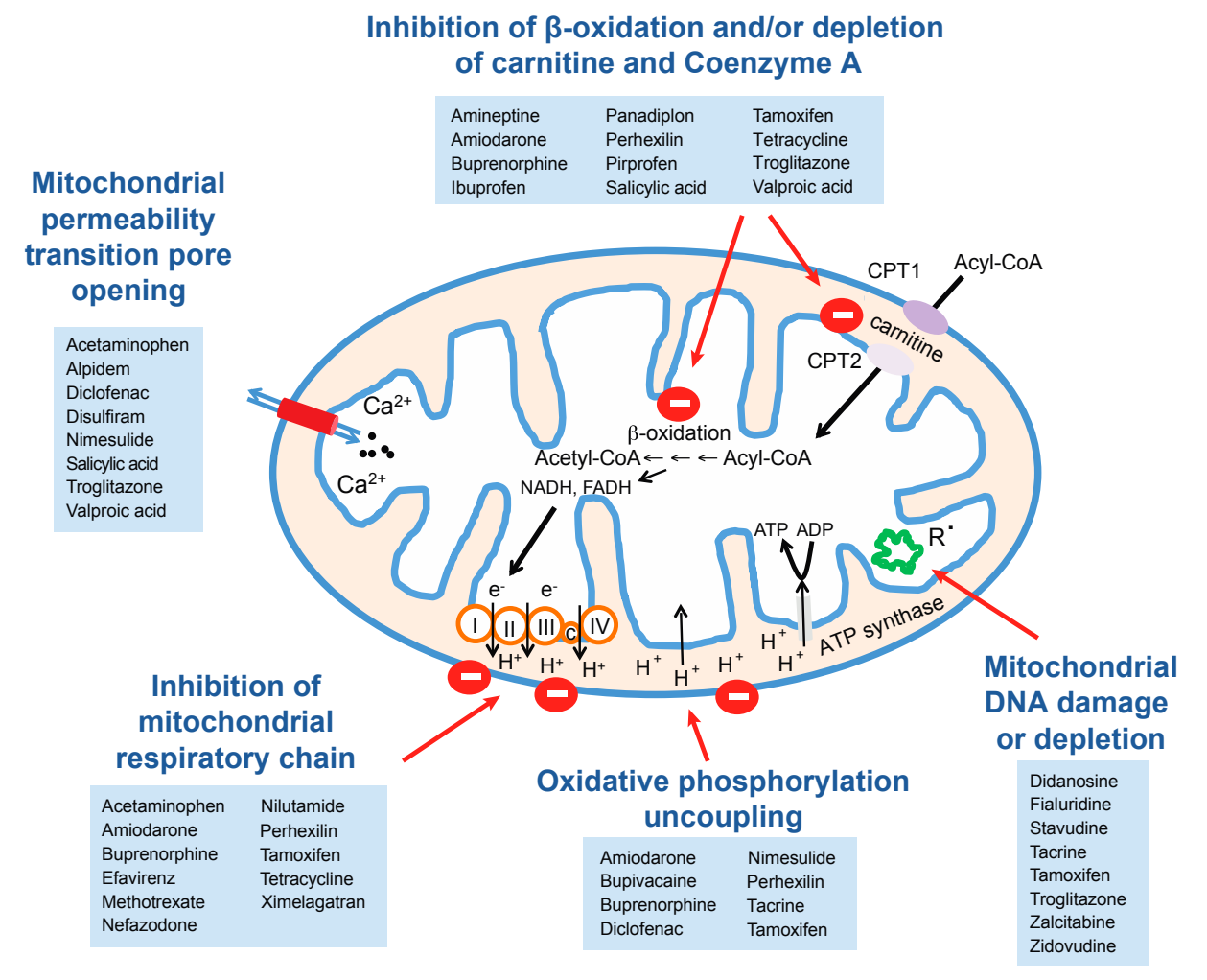

Figure 2. Schematic depiction of hepatotoxic drugs and their respective mitochondrial targets. Medications can exert toxic effects on mitochondria by targeting a variety of different processes, such as inhibition of mitochondrial respiratory chain components, uncoupling of oxidative phosphorylation or inhibition of $\beta$-oxidation and/or depletion of carnitine or coenzyme A. Some compounds, mostly antiretrovirals, can furthermore cause mitochondrial DNA depletion. Mitochondrial damage can result in opening of the mitochondrial permeability transition pore, causing loss of membrane potential, mitochondrial swelling and cell death by apoptosis or necrosis. The associated references are shown in Table 3. 
Table 3. References describing the mitochondrial effect of the drugs highlighted in Figure 2.

\begin{tabular}{|c|c|c|}
\hline Pathway & Drug & Reference \\
\hline \multirow{8}{*}{$\begin{array}{l}\text { Mitochondrial } \\
\text { permeability } \\
\text { transition } \\
\text { pore opening }\end{array}$} & Acetaminophen & Kon et al., 2004 [64] \\
\hline & Alpidem & Berson et al., 2001 [65] \\
\hline & Diclofenac & Masubuchi et al., 2002 [66] \\
\hline & Disulfiram & Balakirev et al., 2001 [67] \\
\hline & Nimesulide & Mingatto et al., 2000 [68] \\
\hline & Salicylic acid & Trost et al., 1996 [69] \\
\hline & Troglitazone & Tirmenstein et al., 2002 and Lim et al., 2008 [70,71] \\
\hline & Valproic acid & Trost et al., [69] \\
\hline \multirow{11}{*}{$\begin{array}{l}\text { Inhibition of } \\
\text { mitochondrial } \\
\text { respiratory chain }\end{array}$} & Acetaminophen & Meyers et al., 1988, Donnelly et al., 1994 and Lee et al., 2015 [72-74] \\
\hline & Amiodarone & Fromenty et al., 1990 [62] \\
\hline & Buprenorphine & Berson et al., $2001[75]$ \\
\hline & Efavirenz & Blas-Garcia et al., 2010 [59] \\
\hline & Methotrexate & Yamamoto et al., 1988 [76] \\
\hline & Nefazodone & Dykens et al., 2008 [60] \\
\hline & Nilutamide & Berson et al., 1994 [61] \\
\hline & Perhexillin & Deschamps et al., 1994 [77] \\
\hline & Tamoxifen & Cardoso et al., 2001 and Larosche et al., 2007 [78,79] \\
\hline & Tetracycline & Pious and Hawley, 1972 [80] \\
\hline & Ximelagatran & Neve et al., 2015 [63] \\
\hline \multirow{8}{*}{$\begin{array}{l}\text { Oxidative } \\
\text { phosphorylation } \\
\text { uncoupling }\end{array}$} & Amiodarone & Fromenty et al., 1990 [62] \\
\hline & Bupivacaine & Dabadie et al., 1997 [81] \\
\hline & Buprenorphine & Berson et al., 2001 [75] \\
\hline & Diclofenac & Ponsoda et al., 1995 and Syed et al., $2016[82,83]$ \\
\hline & Nimesulide & Mingatto et al., 2002 [84] \\
\hline & Perhexillin & Deschamps et al., 1994 [77] \\
\hline & Tacrine & Berson et al., 1996 [85] \\
\hline & Tamoxifen & Cardoso et al., 2001 [78] \\
\hline \multirow{8}{*}{$\begin{array}{l}\text { Mitochondrial } \\
\text { DNA depletion }\end{array}$} & Didanosine & Walker et al., 2004 [86] \\
\hline & Fialuridine & McKenzie et al., 1995 [87] \\
\hline & Stavudine & Walker et al., 2004 [86] \\
\hline & Tacrine & Mansouri et al., 2003 [88] \\
\hline & Tamoxifen & Larosche et al., 2007 [79] \\
\hline & Troglitazone & Rachek et al., 2009 [89] \\
\hline & Zalcitabine & Walker et al., 2004 [86] \\
\hline & Zidovudine & De la Asuncion et al., 1999 [90] \\
\hline \multirow{12}{*}{$\begin{array}{l}\text { Inhibition of } \\
\beta \text {-oxidation and/or } \\
\text { depletion of } \\
\text { carnitine and } \\
\text { Coenzyme A }\end{array}$} & Amineptine & Le Dinh et al., 1988 [91] \\
\hline & Amiodarone & Kennedy et al., 1996 [92] \\
\hline & Buprenorphine & Berson et al., 2001 [75] \\
\hline & Ibuprofen & Fréneaux et al., 1990 and Baldwin et al., 1998 [93,94] \\
\hline & Panadiplon & Ulrich et al., 1998 [95] \\
\hline & Perhexillin & Deschamps et al., 1994 and Kennedy et al., 1994 [77,92] \\
\hline & Pirprofen & Genève et al., 1987 [96] \\
\hline & Salicylic acid & Deschamps et al., 1991 [97] \\
\hline & Tamoxifen & Larosche et al., 2007 [79] \\
\hline & Tetracyclin & Fréneaux et al., 1988 [98] \\
\hline & Troglitazone & Fulgencio et al., 1996 [99] \\
\hline & Valproic acid & Aires et al., 2010 [100] \\
\hline
\end{tabular}




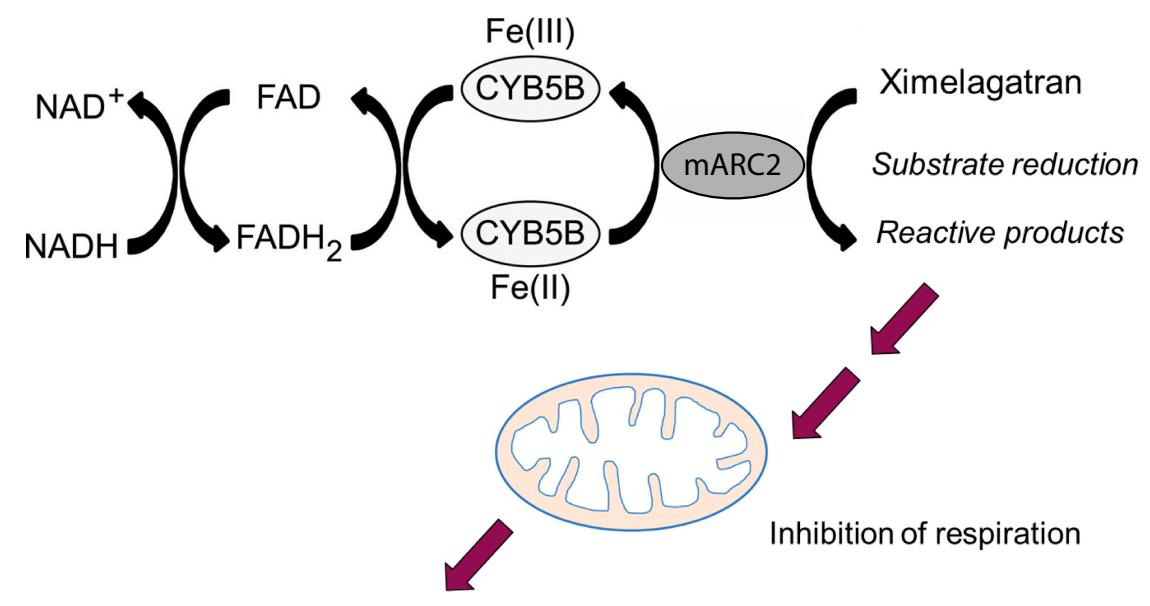

Increased hepatotoxicity

Figure 3. Proposed mechanisms of metabolic activation of ximelagatran. mARC2 in the outer mitochondrial membrane reduces ximelagatran to a reactive metabolite, which in turn inhibits mitochondrial respiration and causes hepatotoxicity.

\subsubsection{Effects on Mitochondrial Lipid Metabolism}

Drugs can also exert direct effects on $\beta$-oxidation by inhibition of the formation of long-chain fatty acids that can enter the mitochondria. Examples of $\beta$-oxidation-inhibiting drugs are troglitazone, amiodarone, valproic acid and salicylate. While all of these drugs inhibit uptake of fatty acids into mitochondria, their underlying mechanisms differ. Troglitazone inhibits long-chain acyl CoA synthetase [99], whereas amiodarone [92] and valproic acid [100] inhibit carnitine acyltransferase I (CPT1), the enzyme responsible for the transfer of the acyl group of long-chain fatty acyl-CoA molecules to carnitine, which constitutes an essential step in mitochondrial $\beta$-oxidation. In contrast, salicylic acid inhibits fatty acid elongation by depleting the cellular CoA-pool due to extensive metabolism of salicate to salicyl-CoA in vivo, thus resulting in impaired fatty acid elongation [97]. Downregulation of $\beta$-oxidation causes perturbations in the metabolic balance, as ketogenesis is impaired with the consequence that extrahepatic cells have to utilize glucose instead as energy source leading to hypoglycemic episodes during fasting periods [101].

\subsubsection{Mitochondrial DNA Damage and Inhibition of Mitochondrial Gene Expression}

Some medications have been shown to act on mitochondrial DNA, transcripts or proteins. Dideoxynucleoside analogs, such as entecavir, used for treatment of chronic hepatitis B or zalcitabine and lamivudine for HIV therapy, constitute molecules that can be incorporated into a growing DNA strand, yet terminate DNA chain elongation due to the lack of a 3'-hydroxyl moiety [102,103]. Importantly, the incorporation of these analogs into replicating DNA strands depends on the specificity of responsible DNA polymerases. While the nucleotide analogs are not incorporated into nuclear DNA due to the specificity of nuclear DNA polymerases, they are incorporated into mitochondrial DNA (mtDNA) by the mitochondrial DNA polymerase $\gamma$ [103]. As a result, these elongation terminating nucleotide analogs have to be removed by the proofreading activity of DNA polymerase $\gamma$, which markedly slows down replication of mtDNA, causes long-term mtDNA depletion and reduces expression of proteins in the mitochondrial respiratory complexes, which are all encoded within the mitochondrial genome [103]. Impaired biosynthesis of respiratory chain components causes the consequences outlined above, including increased ROS formation and reduced pyruvate oxidation [104].

Tetracycline inhibits mitochondrial protein translation, resulting in a stoichiometric imbalance of mitochondrial and nuclear gene products, thus disturbing proteostasis and resulting in unfolded 
protein response within mitochondria [105]. Clinically, this imbalance can manifest as microvesicular steatosis and liver failure [106] due to inhibition of $\beta$-oxidation [98] at high concentrations used in the past.

\subsection{Immune-Mediated Toxicity}

There is growing evidence that some drugs inducing DILI, constitute priming factors that initiate the recruitment and activation of immune cells to the liver and thereby cause hepatic injury (reviewed in reference [107]). The liver contains a variety of resident immune cells, including Kupffer and natural killer cells. During liver injury, the resident liver Kupffer cell populations are complemented by infiltrating macrophages expressing distinct surface markers [108]. Interestingly, liver resident Kupffer cells appear to have a liver protective effect, as evidenced by increased toxicity in Kupffer cell-depleted mice upon APAP exposure [109]. In contrast, inactivation of bone marrow-derived macrophages by gadolinium chloride protects from APAP toxicity (ALT levels $28 \mathrm{IU} / \mathrm{L}$ in treated mice vs. $6380 \mathrm{IU} / \mathrm{L}$ in untreated) [110].

Recent research elucidated various associations between HLA alleles and immune-mediated adverse drug reactions that can manifest in a variety of syndromes, such as drug hypersensitivity, systemic lupus erythematosis, Stevens-Johnson syndrome, toxic epidermal necrolysis, agranulocytosis or drug-induced liver injury (Table 4).

Table 4. Pharmacogenetics of immune-mediated adverse drug reactions. NSAID = non-steroidal anti-inflammatory drug; HSS = Hypersensitivity syndrome; SJS = Stevens-Johnson syndrome; TEN = toxic epidermal necrolysis; DILI = Drug-induced liver injury.

\begin{tabular}{|c|c|c|c|c|}
\hline Drug & Class of Drug & HLA Allele & Adverse Reaction & Reference \\
\hline Abacavir & Antiretroviral & $\mathrm{B}^{* 57: 01, \mathrm{DR} 7 \text { and DQ3 }}$ & HSS & [111-113] \\
\hline Hydralazine & Vasodilator & DR4 & SLE & [114] \\
\hline Minocycline & Antibiotic & DQB1 alleles with tyrosine at position 30 & SLE & [115] \\
\hline Carbamazepine & Anticonvulsant & 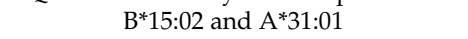 & HSS and SJS/TEN & {$[116-120]$} \\
\hline Phenytoin & Anticonvulsant & $B^{*} 15: 02$ & SJS/TEN & {$[120,121]$} \\
\hline Allopurinol & Uricosuric & $B^{*} 58: 01$ & SJS/TEN & {$[122-125]$} \\
\hline Nevirapine & Antiretroviral & $B^{* 35: 05}$ and $C^{*} 04: 01$ & SJS/TEN & {$[126,127]$} \\
\hline Clozapine & Antipsychotic & Multiple & Agranulocytosis & {$[128,129]$} \\
\hline Flucloxacillin & Antibiotic & $B * 57: 01$ & DILI & [130] \\
\hline Ximelagatran & Anticoagulant & DRB1*07:01 and DQA1*02:01 & DILI & [131] \\
\hline Co-amoxiclav & Antibiotic & DRB1 ${ }^{*} 15: 01$ and $A^{*} 02: 01$ and $B^{*} 18: 01$ & DILI & {$[132-135]$} \\
\hline Lumiracoxib & NSAID & $\mathrm{DRB}^{*} 15: 01$ and DQA*01:02 & DILI & [136] \\
\hline Ticlopidine & Anticoagulant & $A^{* 33: 03}$ & DILI & [137] \\
\hline
\end{tabular}

\subsubsection{Abacavir Hypersensitivity Syndrome (HSS)}

Abacavir is a nucleoside-analog reverse-transcriptase inhibitor against HIV that is routinely used in combinations with other antiretroviral agents, such as lamivudine and zidovudine. Importantly, around $4 \%$ of patients show immune-mediated hypersensitivity to abacavir within the first six weeks of treatment, which mandates the discontinuation of abacavir therapy [138]. Importantly, abacavir hypersensitivity was reproducibly linked to the $H L A-B * 57: 01$ allele (odds ratio $(O R)=117$ ) [111]. The abacavir parent molecule binds non-covalently to $H L A-B^{*} 57: 01$ activating abacavir-specific T-cells, which then cause the systemic hypersensitivity syndrome [112] and introduction of a single variant (S116Y) into the HLA-B*57:01 allele by site-directed mutagenesis abrogated CD8 ${ }^{+} \mathrm{T}$-cell recognition [113]. Double-blind, prospective, randomized clinical trials analyzing the utility of $H L A-B * 57: 01$ genotyping demonstrated a negative predictive value of $100 \%$ and a positive predictive value of $47.9 \%$ [139]. Furthermore, pharmacogenetic testing prior to treatment was mostly found to be cost-effective compared to subsequent treatment of hypersensitivity reactions but could depend on cost of genotyping and efficacy of alternative treatment [140-142]. Screening for the presence of $H L A-B^{*} 57: 01$ has since become required by American (FDA) and European (EMA) regulatory authorities before starting abacavir therapy and thus presents a poster child for the successful implementation of pharmacogenetic research into clinical applications. 


\subsubsection{Systemic Lupus Erythematosus (SLE)}

An increased risk of SLE has been found in individuals exposed to hydralazine (adjusted $O R=6.6$ ), minocycline (adjusted $O R=4.2$ ) and carbamazepine (adjusted $O R=1.9$ ) [143]. SLE is largely determined by heritable factors $(>66 \%)$ with multiple risk alleles located in multiple genes of the major histocompatibility complex (MHC) region or the complement system [144] and associations of $H L A-D R B 1{ }^{*} 03: 01,{ }^{*} 15: 01,{ }^{*} 08: 01$ and ${ }^{*} 14: 01$ with SLE have been consistently replicated [145-148]. Similarly, drug-induced lupus was linked to genetic predisposition, as evidenced by the correlation of minocycline-induced lupus with HLA-DQB1 alleles with tyrosine at position 30 [115] and the association of HLA-DR4 with SLE induced by hydralazine [114].

\subsubsection{Steven Johnson Syndrome (SJS) and Toxic Epidermal Necrolysis (TEN)}

SJS and its more severe form TEN constitute adverse dermatological reactions to medications, which manifest in necrosis and detachment of the epidermis from lower skin layers. Drugs that cause SJS and TEN include carbamazepine, phenytoin, allopurinol and nevirapine. Hypersensitivity reactions to carbamazepine are strongly associated with the presence of $H L A-B^{*} 15: 02$ in various Asian populations [116,117], whereas HLA- $A^{*} 31: 01$ is a strong predictor in Northern Europeans and Japanese [118,119]. Similarly, HLA-B*15:02 was linked to SJS and TEN induced by phenytoin in Han Chinese and Thai $[120,121]$. Furthermore, SJS and TEN due to allopurinol treatment correlated with the $H L A-B * 58: 01$ allele across Asian and European populations [122-125]. Nevirapine is a non-nucleoside reverse transcriptase inhibitor that is part of a combinatorial HIV therapy in developing countries due to its low costs. However, around $20 \%$ of patients show adverse cutaneous reactions that range from localized rashes to SJS and TEN $[149,150]$. The HLA-B*35:05 allele significantly associated with skin rashes in Thais $(O R=9.3)$ but not in African $(O R=0.97)$, Caucasian $(O R=1.79)$ or northeast Asian $(O R=1.53)$ populations [126], whereas the $H L A-C^{*} 04: 01$ allele was linked to nevirapine-induced SJS in Africans $(O R=17.5)$ [127].

\subsubsection{Clozapine-Induced Agranulocytosis}

Clozapine, a dibenzodiazepine shows superior efficacy compared to other antipsychotics but its use is restricted due to high incidences ( $0.8 \%$ after 1 year) of clozapine-induced agranulocytosis [151]. Multiple genetic associations with alleles and single nucleotide polymorphisms (SNPs) in HLA alleles have been reported, including $H L A-D R B 1^{*} 04: 02, D Q B 1^{*} 03: 02, D Q A 1^{*} 0301, H L A-D R^{*} 02$ and $D Q B 1{ }^{*} 05: 02$ as well as variants in HLA-B and HLA-DQB1 [128,129]. However, even in the most comprehensive genetic study of clozapine-induced agranulocytosis performed to date, in which 163 cases were interrogated using genome-wide genotyping and whole-exome sequencing, odds ratios of the identified variants were low, rendering predictive clinical genotyping currently impracticable [129].

\subsubsection{Immune-Related Drug-Induced Liver Injury (DILI)}

Several drugs have been described to cause immune-mediated liver damage. Liver injury due to flucloxacillin shows the strongest genetic HLA-DILI association identified to date with patients harboring the HLA-B*57:01 allele being at 80-fold higher [130], similar in magnitude to the hypersensitivity reactions observed upon abacavir treatment with the same allele $(O R=117)$ [111]. However, while only 13 patients would need to be tested to prevent one case of abacavir hypersensitivity, approximately 14,000 patients would need to be genotyped to prevent one flucloxacillin DILI case due to the low incidence of flucloxacillin DILI (8.5 in 100,000 flucloxacillin-treated patients) [152]. In addition, patients positive for $H L A-B^{*} 57: 01$ (7\% in Caucasians) would be denied flucloxacillin treatment although they would not develop DILI [153]. Thus, despite the strong genetic association, routine screening for $H L A-B^{*} 57: 01$ should not be recommended for flucloxacillin therapy. 
Co-amoxiclav is among the medications most commonly implicated in DILI, accounting for approximately $10 \%$ of DILI cases (after exclusion of acetaminophen cases) [154]. DILI due to amoxicillin-clavulanate significantly correlated with $D R B 1^{*} 15: 01$ in British populations with odds ratios between 2.3 and 9.3 [132-134]. Moreover, additional associations of co-amoxiclav hepatotoxicity with $H L A-A^{*} 02: 01$ and $H L A-B^{*} 18: 01$ were identified in a Spanish population [135]. Interestingly, $H L A-A^{*} 30: 02$ and $H L A-B^{*} 18: 01$ alleles were enriched in cases of hepatocellular injury, whereas $H L A-D R B 1^{*} 15: 01$ significantly associated with cholestatic and mixed DILI manifestations [155]. Corroborating the role of the immune system in amoxicillin-clavulanate, Kim et al. found that amoxicillin- and clavulanate-specific T-cells participate in amoxicillin-clavulanate-induced liver injury [156]. Similarly, risk of toxicity of the COX2-inhibitor lumiracoxib was significantly influenced by the common HLA haplotype HLA-DRB1*15:01-HLA-DQA1*01:02 (OR = 5.0) [136].

Susceptibility to DILI injury due to ticlopidine correlated significantly with the presence of the $H L A-A * 33: 03$ allele in Japanese patients $(O R=13)$ [137]. Ticlopidine is a prodrug that is metabolized mainly by CYP2B6 and CYP2C19 to its active metabolite [157]. Interestingly, studies in 114 individuals with ticlopidine-induced hepatotoxicity indicated that the HLA-A*33:03 related risk to develop DILI was further increased by gain-of-function variants in CYP2B6 (CYP2B6*1H and ${ }^{*} 1 \mathrm{~J}$; OR = 39), thus providing an interesting example of the intricate interplay of drug pharmacokinetics and the immune system in developing DILI [158].

Ximelagatran provides another example for a drug for which the immune system contributes to hepatotoxicity mechanisms has been proposed [131]. Eight percent of patients treated with ximelagatran showed dose-independent, delayed elevations of serum alanine aminotransferase (ALAT) levels resulting in the termination of the clinical development program of the drug [159]. Presence of the HLA-DRB1*07:01 allele was found to correlate with ximelagatran DILI $(O R=4.4)$ and its genetic distribution matches the geographic pattern of ALAT elevations (highest in Scandinavia and low in Asian populations) [131,159].

\section{The Impact of Liver Diseases on Drug Response}

Liver disease may have complex effects on drug clearance, biotransformation, and pharmacokinetics. Pathogenetic factors include alterations in intestinal absorption, plasma protein binding, hepatic extraction ratio, liver blood flow, porto-systemic shunting, biliary excretion, enterohepatic circulation, and renal clearance. For medications with intermediate to high hepatic extraction ratios, these effects can increase levels of bioavailable drug, mandating therapy at lower dosage. For instance, oral bioavailability of chlormethiazole and carvedilol is increased 12- and four-fold, respectively, in patients with liver cirrhosis [160,161]. Furthermore, shunting, sinusoidal capillarization and reduced liver perfusion can impair the functionality of oxidases, such as the CYP enzymes, due to reduced intracellular levels of molecular oxygen [162].

Activities of CYP2E1, CYP2D6, CYP1A2 and CYP2C19 were all found to decrease with increasing hepatic disease severity, their activities were differentially affected [163]. Activity of CYP2E1 was only lost in patients with decompensated cirrhosis, and also CYP2D6 function was relatively preserved. In contrast, CYP1A2 activity was found to decrease linearly with decreasing liver functions and metabolism of mephenytoin by CYP2C19 was already severely impaired by $63 \%$ in patients with mild liver disease (Pugh score 5 or 6) [163]. Similarly, activities of CYP3As were found to decrease in cirrhotic patients $[164,165]$. Corroborating these findings, hepatic expression of CYP1A2, CYP2E1 and CYP3A was found to be reduced in cirrhotic and severely cholestatic patients [166,167]. Consequently, these combined findings indicate that starting doses of CYP2D6, CYP2E1 and CYP3A4 substrates should be adjusted in patients with moderate or severe liver disease, whereas a dose reduction of CYP2C19 and CYP1A2 substrates should already be considered in milder forms of liver disease.

In contrast to the reduction of CYP activities, data on phase II metabolism in cirrhotic patients are conflicting. While some studies indicated that glucuronidation of benzodiazepines was not 
affected in cirrhotic patients [168,169], others showed reduced glucuronidation of morphine [170], zidovudine [171] and lamotrigine [172] in patients with advanced cirrhosis.

Besides cirrhosis, also other liver diseases can markedly impact on hepatic clearance and metabolism. Fisher et al. analyzed expression levels and metabolic capacities of CYPs during non-alcoholic fatty liver disease (NAFLD) progression [173]. Importantly, the authors found that activities of CYP1A2 and CYP2C19 decreased whereas metabolic capacities of CYP2A6 and CYP2C9 increased during progression from healthy livers to steatosis and non-alcoholic steatohepatitis (NASH). Similarly, CYP3A activity decreased in patients with hepatic steatosis [174]. While data on expression of CYP2E1 on the level of mRNA and protein are conflicting [173,175-177], enzymatic activities have been demonstrated to be increased in steatotic and NASH patients [175,178,179].

In addition to a reduction in CYP activity, multiple studies also described impaired phase II metabolism. Younossi et al. analyzed the liver proteomes of 98 obese patients and found, among others, a marked reduction of GSTM1, GSTM2 and GSTM4 (60\% reduction) in patients with hepatic steatosis [180]. Furthermore, MGST2 was found to be downregulated in African NASH patients by $49 \%$ [181]. Interestingly, expression of efflux transporters of the ABC superfamily ( $A B C C 1, A B C C 3-6$, $A B C B 1, A B C G 2)$ increased with NAFLD progression from steatosis to NASH, whereas reduced glycosylation of MRP2 (encoded by $A B C C 2$ ) resulted in reduced functional levels of this transporter at the apical plasma membrane [182]. Similarly, biliary transporters BSEP (ABCB11) and NTCP (SLC10A1) were found to be downregulated in NASH patients [183]. Altered transporter expression profiles can have direct impacts on drug disposition as demonstrated by altered metabolite concentrations in pediatric NASH patients upon a single APAP dose [184]. Specifically, APAP-glucuronide concentrations were increased in serum and urine, most likely due to reduced MRP2 and increased MRP3 activity, whereas APAP-sulfate levels were reduced, in agreement with previous reports [182,183].

Combined, the highlighted studies emphasize the pronounced impacts that hepatic diseases can have on drug ADME and shed light on the underlying molecular mechanisms on which these inter-individual differences are based on. This altered functionality of enzymes and transporters due to liver disease likely translates clinically into altered drug response.

\section{Epigenetics and Inter-Individual Differences}

Environmental as well as pathophysiological factors can moreover affect the epigenomic landscape. In seminal work by Murphy et al., the authors uncovered significant changes of DNA methylation patterns in liver biopsies that encompassed 69,247 DNA elements that correlated with progression of NAFLD [185]. Interestingly, epigenetic signatures matched expression changes in extracellular matrix remodeling factors, inflammatory molecules and ADME genes, including CYP2C19 and SLCO1B3, fueling the hypothesis that altered DNA methylation in concert with histone modifications modulate gene activity and contribute to disease progression. Furthermore, epigenetic factors can provide mechanistic explanations for perturbations of drug metabolism in liver disease.

In the last decade, detailed epigenetic studies identified at least 60 ADME genes under epigenetic regulation and DNA methylation was in strong anti-correlation with gene expression [186]. The CYP3A4 locus constitutes an impressive example for an epigenetic element involved in ADME gene expression. Activities of CYP3A4 can differ around 40-fold [187] and heritable factors have been estimated to account for $90 \%$ of this variability [188]. Interestingly, methylation of DNA elements in the proximal promoter or transcription factor binding sites correlated significantly with hepatic CYP3A4 expression [189]. Recent research indicated that cytosine hydroxymethylation (5hmC) constitutes an additional epigenetic DNA modification, which is present on $0.5 \%-1 \%$ of total cytosine residues in adult human liver [190]. Interestingly, $5 \mathrm{hmC}$ levels have been found to correlate with the hepatic expression of ADME genes whereas no such correlation was detectable with conventional bisulfite sequencing, which is not capable of resolving between methylation and hydroxymethylation marks [191]. Combined, these data suggest a regulatory role of hydroxymethylation in liver development, homeostasis and metabolism. 
However, while epigenetic and epigenomic studies convincingly indicate correlations between epigenetic alterations and gene expression changes, the question about causality remains. The advent of CRISPR/Cas9-based genomic editing tools that allow recruiting functional domains to loci of interest opens up possibilities to interrogate the impact of targeted epigenetic alterations on transcriptional outputs [192]. These developments fuel hopes that the epigenetic cause-consequence enigma can soon be tackled to provide understanding whether changes in gene expression profiles shape the epigenomic landscape, thereby reinforcing already established patterns or whether epigenetic factors are initial priming signals that render genetic loci permissive for transcription.

\section{In Vitro Toxicity Models That Reflect Patient-Specific Factors}

In order to accurately predict hepatic drug response and toxicity, experimental model systems are needed that closely recapitulate and maintain the patient-specific factors outlined above. Primary human hepatocytes $(\mathrm{PHH})$ are the most sensitive in vitro cell system and reflect molecular phenotypes of human hepatocytes in vivo most closely [193,194]. However, their physiological phenotypes are lost in conventional 2D monolayer cultures due to the lack of necessary biochemical cues and cell-cell interactions as well as non-physiological biophysical properties of the culture substratum, e.g., with regards to stiffness $[195,196]$. As a consequence, PHH lose expression of genes characteristic for mature hepatocytes within hours of culture and acquire fetal-like phenotypes [197-199]. To prevent this dedifferentiation a variety of advanced 3D hepatocyte culture methodologies have been developed (extensively reviewed in reference [200]). Hepatic cells can be cultured in stirred bioreactors, hanging drops or ultra-low attachment plates resulting in the formation of cellular aggregates termed spheroids. In spheroid culture, $\mathrm{PHH}$ remain viable and have been shown to retain high-level expression and metabolic capacity of hepatic genes [201-203]. Importantly, the inter-individual variability of hepatocytes isolated from different donors is maintained in spheroid cultures as evidenced by whole proteome analyses, which allows to emulate and study patient diversity in liver biology and drug response [203].

In addition to the maintenance of patient-specific molecular phenotypes in vitro, model systems are needed that incorporate hepatic diseases. To this end, the spheroid system can be expanded to mimic various hepatic pathologies. Drug-induced cholestasis can be replicated as exemplified by treatment with chlorpromazine resulting in significant downregulation of $A B C B 11$, encoding the bile acid transporter BSEP, and a marked accumulation of intra-cellular bile acids [203]. Moreover, 3D systems present pathophysiologically relevant model systems to study the hepatic manifestations of metabolic syndrome and type 2 diabetes mellitus (T2DM). Hepatocytes in such models can remain sensitive to insulin signaling for multiple weeks in normoglycemic conditions, whereas hepatocellular steatosis is induced under elevated glucose exposure [204]. Furthermore, as hepatocytes can be co-cultured with various non-parenchymal cells (NPCs), including Kupffer, stellate and biliary cells, advanced 3D models offer the potential to be useful in simulating NAFLD progression from steatosis to NASH and fibrosis [203].

Combined, advancements in hepatocyte culture technologies allow capturing liver biology, hepatic metabolism and liver pathology more and more accurately, thus opening possibilities to improve the quality of preclinical toxicity assessments in drug development. Furthermore, given the appropriate culture conditions, the spheroid systems indicated above constitutes a suitable tool to study the factors underlying the inter-individual variability in drug response. As such, they might become viable options to perform small "clinical trials" in vitro before entering clinical development stages with high cost-saving potentials for the pharmaceutical industry and reduced risks for trial participants.

\section{Conclusions}

Personalized medicine, defined as the individualization of prevention, diagnosis and treatment, is conceptually nothing new. However, it has received growing attention due to the extended opportunities that came with the recent progress in sequencing technology and data interpretation, 
expanding the patient-specific factors that can be considered from classical parameters such as weight, age and clinical chemistry readouts to complex genetic predictors.

The liver is an organ of central importance in the individualization of treatment due to its critical role in drug metabolism and a plethora of associations of genotypes with drug metabolism and/or toxicity have by now been convincingly described. Most commonly, these variants can be found in ADME genes modulating expression levels or resulting in increased or decreased activity of their respective gene products, thereby changing absorption, bioactivation, detoxification or excretion of the administered medication, resulting in reduced efficacy or increased toxicity. Perturbation of mitochondrial functions is a common mechanism of drug-induced toxicity. It can occur due to inhibition of mitochondrial respiration, inhibition of lipid metabolism or damage to mitochondrial DNA (Figure 2). Furthermore, drugs can directly or indirectly open the mitochondrial permeability pore, thus inducing apoptosis.

Besides impacting drug metabolism, genetic variants can also modulate the risk of immune-mediated toxicity reactions. This relationship of immune system and drug toxicity is best understood for the hypersensitivity reactions upon abacavir treatment that occur exclusively in patients harboring $H L A-B^{*} 57: 01, H L A-D R 7$, and $H L A-D Q 3$ (positive predictive value of $100 \%$ and a negative predictive value of 97\%) [111], in which abacavir has been shown to non-covalently interact with $H L A-B^{*} 57: 01$, triggering a CD8 ${ }^{+} \mathrm{T}$-cell response [112]. However, a growing body of literature indicates that pharmacogenetic associations with variants in major histocompatibility complex (MHC) genes are more common (Table 2).

Liver diseases are another important factor that can influence drug metabolism and clearance and, accordingly, treatment response. Interestingly, drug-metabolizing enzymes were differentially sensitive towards liver diseases, as evidenced by drastically reduced CYP2C19 activity in patients with mild liver disease, whereas CYP2E1 activity only decreased in decompensated cirrhosis [163]. Pathologies, dietary and environmental factors cause alterations of the epigenomic landscape, which has spurred the exploration into epigenetic biomarkers that could predict drug response or treatment outcome ideally from bodily fluids. Some epigenetic biomarkers, such as hypermethylated fragments of SEPT9 in plasma for colorectal cancer diagnosis (sensitivity $90 \%$, specificity $88 \%$, reference [205]) and $A P C$, GSTP1 and RARB2 promoter hypermethylation in urine for prostate cancer detection (sensitivity $69 \%$, specificity $82 \%$, reference [206]) have shown promise for disease diagnosis. They have been made commercially available (e.g., ProCaM ${ }^{\mathrm{TM}}$ and ${ }^{\mathrm{m}} \mathrm{SEPT} 9$ ) but, so far, have not been adopted in routine clinical screening programs. In contrast, to our knowledge no blood-based biomarker predictive of drug response has been identified, thus suggesting that non-invasive pharmacoepigenomics will not be clinically implemented in the near future.

Currently, only $1.3 \%$ of candidate drugs (CDs) entering clinical trials acquire regulatory approval, many due to safety concerns [23,207]. Importantly, increasing confidence in preclinical safety profiles of a CD drastically decreases the likelihood of termination of the respective project in clinical stages due to safety concerns [23]. Combined, these data suggest that current preclinical systems, such as conventional 2D cell culture systems and laboratory animals, do not accurately mimic human drug response. Hence, more predictive preclinical systems are required to increase success rates in clinical stages of the drug development pipeline, resulting in decreased morbidity and mortality of trial participants and decreased costs for the trial sponsor. To address this need, a plethora of advanced 3D cell culture systems were developed, some of which represent significant advancements by enabling chronic toxicity assessments at exposure levels that approximate therapeutic concentrations. While hepatocytes isolated from different patients can retain their inter-individual differences in 3D systems and have been successfully applied to mimic hepatocellular injuries due to mitochondrial toxicity and metabolic alterations in diseased conditions, the capture of idiosyncratic immune-mediated responses remains currently unpredictable.

While results obtained with these systems are encouraging, the field requires the standardization of protocols and systematic validation studies, ideally performed in a joint cross-pharma setting, 
to facilitate wider adoption in academia and industry with the long-term aim of acceptance by regulatory bodies.

Acknowledgments: The research in the laboratory is financed by European Union's Horizon 2020 research and innovation programme under grant agreement No. 668353, by The Swedish Research Council, by the European Community under the Innovative Medicine Initiative project MIP-DILI (grant agreement number 115336) and by The Swedish Cancer Foundation.

Author Contributions: Volker M. Lauschke wrote and finalized the manuscript. Magnus Ingelman-Sundberg edited the manuscript and contributed to figures.

Conflicts of Interest: The authors are founders and owners of HepaPredict AB.

\section{References}

1. Spear, B.B.; Heath-Chiozzi, M.; Huff, J. Clinical application of pharmacogenetics. Trends Mol. Med. 2001, 7, 201-204. [CrossRef]

2. Sim, S.C.; Kacevska, M.; Ingelman-Sundberg, M. Pharmacogenomics of drug-metabolizing enzymes: A recent update on clinical implications and endogenous effects. Pharmacogenom. J. 2012, 13, 1-11. [CrossRef] [PubMed]

3. Frueh, F.W.; Amur, S.; Mummaneni, P.; Epstein, R.S.; Aubert, R.E.; DeLuca, T.M.; Verbrugge, R.R.; Burckart, G.J.; Lesko, L.J. Pharmacogenomic Biomarker Information in Drug Labels Approved by the United States Food and Drug Administration: Prevalence of Related Drug Use. Pharmacotherapy 2008, 28, 992-998. [CrossRef] [PubMed]

4. Ehmann, F.; Caneva, L.; Prasad, K.; Paulmichl, M.; Maliepaard, M.; Llerena, A.; Ingelman-Sundberg, M.; Papaluca-Amati, M. Pharmacogenomic information in drug labels: European Medicines Agency perspective. Pharmacogenom. J. 2015, 15, 201-210. [CrossRef] [PubMed]

5. Haga, S.B.; Mills, R.; Moaddeb, J. Pharmacogenetic information for patients on drug labels. Pharmacogenom. Pers. Med. 2014, 7, 297-305.

6. Carr, D.; Alfirevic, A.; Pirmohamed, M. Pharmacogenomics: Current State-of-the-Art. Genes 2014, 5, 430-443. [CrossRef] [PubMed]

7. Lauschke, V.M.; Ingelman-Sundberg, M. Requirements for comprehensive pharmacogenetic genotyping platforms. Pharmacogenomics 2016, 17, 917-924. [CrossRef] [PubMed]

8. CPIC Guidelines for Gene-Drug Interactions. Available online: https://cpicpgx.org/genes-drugs (accessed on 12 July 2016).

9. Fujikura, K.; Ingelman-Sundberg, M.; Lauschke, V.M. Genetic variation in the human cytochrome P450 supergene family. Pharmacogenet. Genom. 2015, 25, 584-594. [CrossRef] [PubMed]

10. Gordon, A.S.; Tabor, H.K.; Johnson, A.D.; Snively, B.M.; Assimes, T.L.; Auer, P.L.; Ioannidis, J.P.A.; Peters, U.; Robinson, J.G.; Sucheston, L.E.; et al. Quantifying rare, deleterious variation in 12 human cytochrome P450 drug-metabolism genes in a large-scale exome dataset. Hum. Mol. Genet. 2014, 23, 1957-1963. [CrossRef] [PubMed]

11. Kozyra, M.; Ingelman-Sundberg, M.; Lauschke, V.M. Rare genetic variants in cellular transporters, metabolic enzymes, and nuclear receptors can be important determinants of interindividual differences in drug response. Genet. Med. 2016. [CrossRef] [PubMed]

12. Lauschke, V.M.; Ingelman-Sundberg, M. Precision Medicine and Rare Genetic Variants. Trends Pharmacol. Sci. 2016, 37, 85-86. [CrossRef] [PubMed]

13. Pirmohamed, M.; James, S.; Meakin, S.; Green, C.; Scott, A.K.; Walley, T.J.; Farrar, K.; Park, B.K.; Breckenridge, A.M. Adverse drug reactions as cause of admission to hospital: Prospective analysis of 18820 patients. Br. Med. J. 2004, 329, 15-19. [CrossRef] [PubMed]

14. Impicciatore, P.; Choonara, I.; Clarkson, A.; Provasi, D.; Pandolfini, C.; Bonati, M. Incidence of adverse drug reactions in paediatric in/out-patients: A systematic review and meta-analysis of prospective studies. Br. J. Clin. Pharmacol. 2001, 52, 77-83. [CrossRef] [PubMed]

15. Routledge, P.A.; O'Mahony, M.S.; Woodhouse, K.W. Adverse drug reactions in elderly patients. Br. J. Clin. Pharmacol. 2003, 57, 121-126. [CrossRef]

16. Budnitz, D.S.; Shehab, N.; Kegler, S.R.; Richards, C.L. Medication use leading to emergency department visits for adverse drug events in older adults. Ann. Intern. Med. 2007, 147, 755-765. [CrossRef] [PubMed] 
17. Bates, D.W.; Spell, N.; Cullen, D.J.; Burdick, E.; Laird, N.; Petersen, L.A.; Small, S.D.; Sweitzer, B.J.; Leape, L.L. The costs of adverse drug events in hospitalized patients. Adverse drug events prevention study group. J. Am. Med. Assoc. 1997, 277, 307-311. [CrossRef]

18. Gautier, S.; Bachelet, H.; Bordet, R.; Caron, J. The cost of adverse drug reactions. Exp. Opin. Pharmacother. 2005, 4, 319-326. [CrossRef] [PubMed]

19. Hug, B.L.; Keohane, C.; Seger, D.L.; Yoon, C.; Bates, D.W. The costs of adverse drug events in community hospitals. Jt. Comm. J. Qual. Patient Saf. 2012, 38, 120-126. [PubMed]

20. Johnson, J.A.; Bootman, J.L. Drug-related morbidity and mortality and the economic impact of pharmaceutical care. Am. J. Health Syst. Pharm. 1997, 54, 554-558. [PubMed]

21. Faich, G.A.; Knapp, D.; Dreis, M.; Turner, W. National adverse drug reaction surveillance: 1985. J. Am. Med. Assoc. 1987, 257, 2068-2070. [CrossRef]

22. Goettler, M.; Schneeweiss, S.; Hasford, J. Adverse drug reaction monitoring-cost and benefit considerations. Part II: Cost and preventability of adverse drug reactions leading to hospital admission. Pharmacoepidemiol. Drug Saf. 1997, 6, S79-S90. [CrossRef]

23. Cook, D.; Brown, D.; Alexander, R.; March, R.; Morgan, P.; Satterthwaite, G.; Pangalos, M.N. Lessons learned from the fate of AstraZeneca's drug pipeline: A five-dimensional framework. Nat. Rev. Drug Discov. 2014, 13, 419-431. [CrossRef] [PubMed]

24. Manning, F.J.; Swartz, M. Review of the Fialuridine (FIAU) Clinical Trials; National Academies Press: Atlanta, GA, USA, 1995.

25. Kaku, K.; Enya, K.; Nakaya, R.; Ohira, T.; Matsuno, R. Efficacy and safety of fasiglifam (TAK-875), a G protein-coupled receptor 40 agonist, in Japanese patients with type 2 diabetes inadequately controlled by diet and exercise: A randomized, double-blind, placebo-controlled, phase III trial. Diabetes Obes. Metab. 2015, 17, 675-681. [CrossRef] [PubMed]

26. Lasser, K.E.; Allen, P.D.; Woolhandler, S.J.; Himmelstein, D.U.; Wolfe, S.M.; Bor, D.H. Timing of new black box warnings and withdrawals for prescription medications. J. Am. Med. Assoc. 2002, 287, 2215-2220. [CrossRef]

27. Amstutz, U.; Froehlich, T.K.; Largiadèr, C.R. Dihydropyrimidine dehydrogenase gene as a major predictor of severe 5-fluorouracil toxicity. Pharmacogenomics 2011, 12, 1321-1336. [CrossRef] [PubMed]

28. Evans, W.E.; Hon, Y.Y.; Bomgaars, L.; Coutre, S.; Holdsworth, M.; Janco, R.; Kalwinsky, D.; Keller, F.; Khatib, Z.; Margolin, J.; et al. Preponderance of thiopurine S-methyltransferase deficiency and heterozygosity among patients intolerant to mercaptopurine or azathioprine. J. Clin. Oncol. 2001, 19, 2293-2301. [PubMed]

29. Lennard, L. TPMT in the treatment of Crohn's disease with azathioprine. Gut 2002, 51, 143-146. [CrossRef] [PubMed]

30. Gasche, Y.; Daali, Y.; Fathi, M.; Chiappe, A.; Cottini, S.; Dayer, P.; Desmeules, J. Codeine intoxication associated with ultrarapid CYP2D6 metabolism. N. Engl. J. Med. 2004, 351, 2827-2831. [CrossRef] [PubMed]

31. Innocenti, F.; Undevia, S.D.; Iyer, L.; Chen, P.X.; Das, S.; Kocherginsky, M.; Karrison, T.; Janisch, L.; Ramírez, J.; Rudin, C.M.; et al. Genetic variants in the UDP-glucuronosyltransferase 1A1 gene predict the risk of severe neutropenia of irinotecan. J. Clin. Oncol. 2004, 22, 1382-1388. [CrossRef] [PubMed]

32. Wang, G.; Lei, H.-P.; Li, Z.; Tan, Z.-R.; Guo, D.; Fan, L.; Chen, Y.; Hu, D.-L.; Wang, D.; Zhou, H.-H. The CYP2C19 ultra-rapid metabolizer genotype influences the pharmacokinetics of voriconazole in healthy male volunteers. Eur. J. Clin. Pharmacol. 2008, 65, 281-285. [CrossRef] [PubMed]

33. Holmes, M.V.; Perel, P.; Shah, T.; Hingorani, A.D.; Casas, J.P. CYP2C19 Genotype, Clopidogrel Metabolism, Platelet Function, and Cardiovascular Events A Systematic Review and Meta-analysis. J. Am. Med. Assoc. 2011, 306, 2704-2714. [CrossRef] [PubMed]

34. Johnson, J.A.; Gong, L.; Whirl-Carrillo, M.; Gage, B.F.; Scott, S.A.; Stein, C.M.; Anderson, J.L.; Kimmel, S.E.; Lee, M.T.M.; Pirmohamed, M.; et al. Clinical Pharmacogenetics Implementation Consortium Guidelines for CYP2C9 and VKORC1 Genotypes and Warfarin Dosing. Clin. Pharmacol. Ther. 2011, 90, 625-629. [CrossRef] [PubMed]

35. Furuta, T.; Ohashi, K.; Kamata, T.; Takashima, M.; Kosuge, K.; Kawasaki, T.; Hanai, H.; Kubota, T.; Ishizaki, T.; Kaneko, E. Effect of genetic differences in omeprazole metabolism on cure rates for Helicobacter pylori infection and peptic ulcer. Ann. Intern. Med. 1998, 129, 1027-1030. [CrossRef] [PubMed] 
36. Furuta, T.; Shirai, N.; Takashima, M.; Xiao, F.; Hanai, H.; Sugimura, H.; Ohashi, K.; Ishizaki, T.; Kaneko, E. Effect of genotypic differences in CYP2C19 on cure rates for Helicobacter pylori infection by triple therapy with a proton pump inhibitor, amoxicillin, and clarithromycin. Clin. Pharmacol. Ther. 2001, 69, 158-168. [CrossRef] [PubMed]

37. Link, E.; Parish, S.; Armitage, J.; Bowman, L.; Heath, S.; Matsuda, F.; Gut, I.; Lathrop, M.; Collins, R. SLCO1B1 variants and statin-induced myopathy-A genomewide study. N. Engl. J. Med. 2008, 359, 789-799. [PubMed]

38. Wang, L.; McLeod, H.L.; Weinshilboum, R.M. Genomics and drug response. N. Engl. J. Med. 2011, 364, 1144-1153. [PubMed]

39. Hertz, D.L.; Rae, J. Pharmacogenetics of Cancer Drugs. Annu. Rev. Med. 2015, 66, 65-81. [CrossRef] [PubMed]

40. Relling, M.V.; Evans, W.E. Pharmacogenomics in the clinic. Nature 2015, 526, 343-350. [CrossRef] [PubMed]

41. Abecasis, G.R.; Chakravarti, A.; Donnelly, P.; Eichler, E.E.; Gabriel, S.B.; Hurles, M.E.; Mardis, E.R.; Nickerson, D.A.; Gibbs, R.A.; Boerwinkle, E.; et al. A global reference for human genetic variation. Nature 2015, 526, 68-74.

42. Tennessen, J.A.; Bigham, A.W.; O'Connor, T.D.; Fu, W.; Kenny, E.E.; Gravel, S.; McGee, S.; Do, R.; Liu, X.; Jun, G.; et al. Evolution and functional impact of rare coding variation from deep sequencing of human exomes. Science 2012, 337, 64-69. [CrossRef] [PubMed]

43. Perry, J.R.B.; Xu, C.; Lawson, D.; Hendricks, A.E.; Barroso, I.; Hurles, M.E.; Greenwood, C.M.T.; Bala, S.; Clapham, P.; Coates, G.; et al. The UK10K project identifies rare variants in health and disease. Nature 2015, $526,82-90$.

44. Ragoussis, J. Genotyping Technologies for Genetic Research. Annu. Rev. Genom. Hum. Genet. 2009, 10, 117-133. [CrossRef] [PubMed]

45. Manolio, T.A. Bringing genome-wide association findings into clinical use. Nat. Rev. Genet. 2013, 14, 549-558. [CrossRef] [PubMed]

46. Matthaei, J.; Brockmöller, J.; Tzvetkov, M.V.; Sehrt, D.; Sachse-Seeboth, C.; Hjelmborg, J.B.; Möller, S.; Halekoh, U.; Hofmann, U.; Schwab, M.; et al. Heritability of metoprolol and torsemide pharmacokinetics. Clin. Pharmacol. Ther. 2015, 98, 611-621. [CrossRef] [PubMed]

47. Kaplowitz, N. Idiosyncratic drug hepatotoxicity. Nat. Rev. Drug Discov. 2005, 4, 489-499. [CrossRef] [PubMed]

48. Dobo, K.L.; Obach, R.S.; Luffer-Atlas, D.; Bercu, J.P. A Strategy for the Risk Assessment of Human Genotoxic Metabolites. Chem. Res. Toxicol. 2009, 22, 348-356. [CrossRef] [PubMed]

49. Orr, S.T.M.; Ripp, S.L.; Ballard, T.E.; Henderson, J.L.; Scott, D.O.; Obach, R.S.; Sun, H.; Kalgutkar, A.S. Mechanism-Based Inactivation (MBI) of Cytochrome P450 Enzymes: Structure-Activity Relationships and Discovery Strategies To Mitigate Drug-Drug Interaction Risks. J. Med. Chem. 2012, 55, 4896-4933. [CrossRef] [PubMed]

50. Kitteringham, N.R.; Kenna, J.G.; Park, B.K. Detection of autoantibodies directed against human hepatic endoplasmic reticulum in sera from patients with halothane-associated hepatitis. Br. J. Clin. Pharmacol. 1995, 40, 379-386. [CrossRef] [PubMed]

51. Cheng, L.; You, Q.; Yin, H.; Holt, M.P.; Ju, C. Involvement of natural killer T-cells in halothane-induced liver injury in mice. Biochem. Pharmacol. 2010, 80, 255-261. [CrossRef] [PubMed]

52. Boelsterli, U.A. Xenobiotic acyl glucuronides and acyl CoA thioesters as protein-reactive metabolites with the potential to cause idiosyncratic drug reactions. Curr. Drug Metab. 2002, 3, 439-450. [CrossRef] [PubMed]

53. Aithal, G.P.; Ramsay, L.; Daly, A.K.; Sonchit, N.; Leathart, J.B.S.; Alexander, G.; Kenna, J.G.; Caldwell, J.; Day, C.P. Hepatic adducts, circulating antibodies, and cytokine polymorphisms in patients with diclofenac hepatotoxicity. Hepatology 2004, 39, 1430-1440. [CrossRef] [PubMed]

54. Kalgutkar, A.S.; Dalvie, D. Predicting Toxicities of Reactive Metabolite-Positive Drug Candidates. Annu. Rev. Pharmacol. Toxicol. 2015, 55, 35-54. [CrossRef] [PubMed]

55. Hinson, J.A.; Roberts, D.W.; James, L.P. Adverse Drug Reactions (Handbook of Experimental Pharmacology), 1st ed.; Springer: Berlin/Heidelberg, Germany, 2009; Volume 196, pp. 369-405.

56. Koen, Y.M.; Sarma, D.; Williams, T.D.; Galeva, N.A.; Obach, R.S.; Hanzlik, R.P. Identification of Protein Targets of Reactive Metabolites of Tienilic Acid in Human Hepatocytes. Chem. Res. Toxicol. 2012, 25, 1145-1154. [CrossRef] [PubMed] 
57. Pessayre, D.; Fromenty, B.; Berson, A.; Robin, M.-A.; Lettéron, P.; Moreau, R.; Mansouri, A. Central role of mitochondria in drug-induced liver injury. Drug Metab. Rev. 2012, 44, 34-87. [CrossRef] [PubMed]

58. Watmough, N.J.; Bindoff, L.A.; Birch-Machin, M.A.; Jackson, S.; Bartlett, K.; Ragan, C.I.; Poulton, J.; Gardiner, R.M.; Sherratt, H.S.; Turnbull, D.M. Impaired mitochondrial $\beta$-oxidation in a patient with an abnormality of the respiratory chain. Studies in skeletal muscle mitochondria. J. Clin. Investig. 1990, 85, 177-184. [CrossRef] [PubMed]

59. Blas-García, A.; Apostolova, N.; Ballesteros, D.; Monleón, D.; Morales, J.M.; Rocha, M.; Victor, V.M.; Esplugues, J.V. Inhibition of mitochondrial function by efavirenz increases lipid content in hepatic cells. Hepatology 2010, 52, 115-125. [CrossRef] [PubMed]

60. Dykens, J.A.; Jamieson, J.D.; Marroquin, L.D.; Nadanaciva, S.; Xu, J.J.; Dunn, M.C.; Smith, A.R.; Will, Y. In vitro assessment of mitochondrial dysfunction and cytotoxicity of nefazodone, trazodone, and buspirone. Toxicol. Sci. 2008, 103, 335-345. [CrossRef] [PubMed]

61. Berson, A.; Schmets, L.; Fisch, C.; Fau, D.; Wolf, C.; Fromenty, B.; Deschamps, D.; Pessayre, D. Inhibition by nilutamide of the mitochondrial respiratory chain and ATP formation. Possible contribution to the adverse effects of this antiandrogen. J. Pharmacol. Exp. Ther. 1994, 270, 167-176. [PubMed]

62. Fromenty, B.; Fisch, C.; Berson, A.; Letteron, P.; Larrey, D.; Pessayre, D. Dual effect of amiodarone on mitochondrial respiration. Initial protonophoric uncoupling effect followed by inhibition of the respiratory chain at the levels of complex I and complex II. J. Pharmacol. Exp. Ther. 1990, 255, 1377-1384. [PubMed]

63. Neve, E.P.A.; Köfeler, H.; Hendriks, D.F.G.; Nordling, Å.; Gogvadze, V.; Mkrtchian, S.; Näslund, E.; Ingelman-Sundberg, M. Expression and Function of mARC: Roles in Lipogenesis and Metabolic Activation of Ximelagatran. PLoS ONE 2015, 10, e0138487. [CrossRef] [PubMed]

64. Kon, K.; Kim, J.-S.; Jaeschke, H.; Lemasters, J.J. Mitochondrial permeability transition in acetaminophen-induced necrosis and apoptosis of cultured mouse hepatocytes. Hepatology 2004, 40, 1170-1179. [CrossRef] [PubMed]

65. Berson, A.; Descatoire, V.; Sutton, A.; Fau, D.; Maulny, B.; Vadrot, N.; Feldmann, G.; Berthon, B.; Tordjmann, T.; Pessayre, D. Toxicity of alpidem, a peripheral benzodiazepine receptor ligand, but not zolpidem, in rat hepatocytes: Role of mitochondrial permeability transition and metabolic activation. J. Pharmacol. Exp. Ther. 2001, 299, 793-800. [PubMed]

66. Masubuchi, Y.; Nakayama, S.; Horie, T. Role of mitochondrial permeability transition in diclofenac-induced hepatocyte injury in rats. Hepatology 2002, 35, 544-551. [CrossRef] [PubMed]

67. Balakirev, M.Y.; Zimmer, G. Mitochondrial injury by disulfiram: Two different mechanisms of the mitochondrial permeability transition. Chem. Biol. Interact. 2001, 138, 299-311. [CrossRef]

68. Mingatto, F.E.; dos Santos, A.C.; Rodrigues, T.; Pigoso, A.A.; Uyemura, S.A.; Curti, C. Effects of nimesulide and its reduced metabolite on mitochondria. Br. J. Pharmacol. 2000, 131, 1154-1160. [CrossRef] [PubMed]

69. Trost, L.C.; Lemasters, J.J. The mitochondrial permeability transition: A new pathophysiological mechanism for Reye's syndrome and toxic liver injury. J. Pharmacol. Exp. Ther. 1996, 278, 1000-1005. [PubMed]

70. Tirmenstein, M.A.; Hu, C.X.; Gales, T.L.; Maleeff, B.E.; Narayanan, P.K.; Kurali, E.; Hart, T.K.; Thomas, H.C.; Schwartz, L.W. Effects of troglitazone on HepG2 viability and mitochondrial function. Toxicol. Sci. 2002, 69, 131-138. [CrossRef] [PubMed]

71. Lim, P.L.K.; Liu, J.; Go, M.L.; Boelsterli, U.A. The mitochondrial superoxide/thioredoxin-2/Ask1 signaling pathway is critically involved in troglitazone-induced cell injury to human hepatocytes. Toxicol. Sci. 2008, 101, 341-349. [CrossRef] [PubMed]

72. Meyers, L.L.; Beierschmitt, W.P.; Khairallah, E.A.; Cohen, S.D. Acetaminophen-induced inhibition of hepatic mitochondrial respiration in mice. Toxicol. Appl. Pharmacol. 1988, 93, 378-387. [CrossRef]

73. Donnelly, P.J.; Walker, R.M.; Racz, W.J. Inhibition of mitochondrial respiration in vivo is an early event in acetaminophen-induced hepatotoxicity. Arch. Toxicol. 1994, 68, 110-118. [CrossRef] [PubMed]

74. Lee, K.K.; Imaizumi, N.; Chamberland, S.R.; Alder, N.N.; Boelsterli, U.A. Targeting mitochondria with methylene blue protects mice against acetaminophen-induced liver injury. Hepatology 2015, 61, 326-336. [CrossRef] [PubMed]

75. Berson, A.; Fau, D.; Fornacciari, R.; Degove-Goddard, P.; Sutton, A.; Descatoire, V.; Haouzi, D.; Letteron, P.; Moreau, A.; Feldmann, G.; et al. Mechanisms for experimental buprenorphine hepatotoxicity: Major role of mitochondrial dysfunction versus metabolic activation. J. Hepatol. 2001, 34, 261-269. [CrossRef] 
76. Yamamoto, N.; Oliveira, M.B.; Campello Ade, P.; Lopes, L.C.; Klüppel, M.L. Methotrexate: Studies on the cellular metabolism. I. Effect on mitochondrial oxygen uptake and oxidative phosphorylation. Cell Biochem. Funct. 1988, 6, 61-66. [CrossRef] [PubMed]

77. Deschamps, D.; DeBeco, V.; Fisch, C.; Fromenty, B.; Guillouzo, A.; Pessayre, D. Inhibition by perhexiline of oxidative phosphorylation and the beta-oxidation of fatty acids: Possible role in pseudoalcoholic liver lesions. Hepatology 1994, 19, 948-961. [CrossRef] [PubMed]

78. Cardoso, C.M.P.; Custódio, J.B.A.; Almeida, L.M.; Moreno, A.J.M. Mechanisms of the Deleterious Effects of Tamoxifen on Mitochondrial Respiration Rate and Phosphorylation Efficiency. Toxicol. Appl. Pharmacol. 2001, 176, 145-152. [CrossRef] [PubMed]

79. Larosche, I.; Lettéron, P.; Fromenty, B.; Vadrot, N.; Abbey-Toby, A.; Feldmann, G.; Pessayre, D.; Mansouri, A. Tamoxifen inhibits topoisomerases, depletes mitochondrial DNA, and triggers steatosis in mouse liver. J. Pharmacol. Exp. Ther. 2007, 321, 526-535. [CrossRef] [PubMed]

80. Pious, D.A.; Hawley, P. Effect of antibiotics on respiration in human cells. Pediatr. Res. 1972, 6, 687-692. [CrossRef] [PubMed]

81. Dabadie, P.; Bendriss, P.; Erny, P.; Mazat, J.P. Uncoupling effects of local anesthetics on rat liver mitochondria. FEBS Lett. 1987, 226, 77-82. [CrossRef]

82. Ponsoda, X.; Bort, R.; Jover, R.; Gómez-Lechón, M.J.; Castell, J.V. Molecular mechanism of diclofenac hepatotoxicity: Association of cell injury with oxidative metabolism and decrease in ATP levels. Toxicol. in Vitro 1995, 9, 439-444. [CrossRef]

83. Syed, M.; Skonberg, C.; Hansen, S.H. Mitochondrial toxicity of diclofenac and its metabolites via inhibition of oxidative phosphorylation (ATP synthesis) in rat liver mitochondria: Possible role in drug induced liver injury (DILI). Toxicol. in Vitro 2016, 31, 93-102. [CrossRef] [PubMed]

84. Mingatto, F.E.; Rodrigues, T.; Pigoso, A.A.; Uyemura, S.A.; Curti, C.; Santos, A.C. The critical role of mitochondrial energetic impairment in the toxicity of nimesulide to hepatocytes. J. Pharmacol. Exp. Ther. 2002, 303, 601-607. [CrossRef] [PubMed]

85. Berson, A.; Renault, S.; Letteron, P.; Robin, M.A.; Fromenty, B.; Fau, D.; Le Bot, M.A.; Riché, C.; Durand-Schneider, A.M.; Feldmann, G.; et al. Uncoupling of rat and human mitochondria: A possible explanation for tacrine-induced liver dysfunction. Gastroenterology 1996, 110, 1878-1890. [CrossRef] [PubMed]

86. Walker, U.A.; Bäuerle, J.; Laguno, M.; Murillas, J.; Mauss, S.; Schmutz, G.; Setzer, B.; Miquel, R.; Gatell, J.M.; Mallolas, J. Depletion of mitochondrial DNA in liver under antiretroviral therapy with didanosine, stavudine, or zalcitabine. Hepatology 2004, 39, 311-317. [CrossRef] [PubMed]

87. McKenzie, R.; Fried, M.W.; Sallie, R.; Conjeevaram, H.; Di Bisceglie, A.M.; Park, Y.; Savarese, B.; Kleiner, D.; Tsokos, M.; Luciano, C. Hepatic failure and lactic acidosis due to fialuridine (FIAU), an investigational nucleoside analogue for chronic hepatitis B. N. Engl. J. Med. 1995, 333, 1099-1105. [CrossRef] [PubMed]

88. Mansouri, A.; Haouzi, D.; Descatoire, V.; Demeilliers, C.; Sutton, A.; Vadrot, N.; Fromenty, B.; Feldmann, G.; Pessayre, D.; Berson, A. Tacrine inhibits topoisomerases and DNA synthesis to cause mitochondrial DNA depletion and apoptosis in mouse liver. Hepatology 2003, 38, 715-725. [CrossRef] [PubMed]

89. Rachek, L.I.; Yuzefovych, L.V.; LeDoux, S.P.; Julie, N.L.; Wilson, G.L. Troglitazone, but not rosiglitazone, damages mitochondrial DNA and induces mitochondrial dysfunction and cell death in human hepatocytes. Toxicol. Appl. Pharmacol. 2009, 240, 348-354. [CrossRef] [PubMed]

90. De la Asunción, J.G.; del Olmo, M.L.; Sastre, J.; Pallardó, F.V.; Viña, J. Zidovudine (AZT) causes an oxidation of mitochondrial DNA in mouse liver. Hepatology 1999, 29, 985-987. [CrossRef] [PubMed]

91. Le Dinh, T.; Fréneaux, E.; Labbe, G.; Letteron, P.; Degott, C.; Genève, J.; Berson, A.; Larrey, D.; Pessayre, D. Amineptine, a tricyclic antidepressant, inhibits the mitochondrial oxidation of fatty acids and produces microvesicular steatosis of the liver in mice. J. Pharmacol. Exp. Ther. 1988, 247, 745-750. [PubMed]

92. Kennedy, J.A.; Unger, S.A.; Horowitz, J.D. Inhibition of carnitine palmitoyltransferase-1 in rat heart and liver by perhexiline and amiodarone. Biochem. Pharmacol. 1996, 52, 273-280. [CrossRef]

93. Fréneaux, E.; Fromenty, B.; Berson, A.; Labbe, G.; Degott, C.; Letteron, P.; Larrey, D.; Pessayre, D. Stereoselective and nonstereoselective effects of ibuprofen enantiomers on mitochondrial beta-oxidation of fatty acids. J. Pharmacol. Exp. Ther. 1990, 255, 529-535. [PubMed] 
94. Baldwin, G.S.; Murphy, V.J.; Yang, Z.; Hashimoto, T. Binding of nonsteroidal antiinflammatory drugs to the alpha-subunit of the trifunctional protein of long chain fatty acid oxidation. J. Pharmacol. Exp. Ther. 1998, 286, 1110-1114. [PubMed]

95. Ulrich, R.G.; Bacon, J.A.; Cramer, C.T.; Petrella, D.K.; Sun, E.L.; Meglasson, M.D.; Holmuhamedov, E. Disruption of mitochondrial activities in rabbit and human hepatocytes by a quinoxalinone anxiolytic and its carboxylic acid metabolite. Toxicology 1998, 131, 33-47. [CrossRef]

96. Genève, J.; Hayat-Bonan, B.; Labbe, G.; Degott, C.; Letteron, P.; Fréneaux, E.; Le Dinh, T.; Larrey, D.; Pessayre, D. Inhibition of mitochondrial $\beta$-oxidation of fatty acids by pirprofen. Role in microvesicular steatosis due to this nonsteroidal anti-inflammatory drug. J. Pharmacol. Exp. Ther. 1987, 242, 1133-1137. [PubMed]

97. Deschamps, D.; Fisch, C.; Fromenty, B.; Berson, A.; Degott, C.; Pessayre, D. Inhibition by salicylic acid of the activation and thus oxidation of long chain fatty acids: Possible role in the development of Reye's syndrome. J. Pharmacol. Exp. Ther. 1991, 259, 894-904. [PubMed]

98. Fréneaux, E.; Labbe, G.; Letteron, P.; Dinh, T.L.; Degott, C.; Genève, J.; Larrey, D.; Pessayre, D. Inhibition of the mitochondrial oxidation of fatty acids by tetracycline in mice and in man: Possible role in microvesicular steatosis induced by this antibiotic. Hepatology 1988, 8, 1056-1062. [CrossRef] [PubMed]

99. Fulgencio, J.-P.; Kohl, C.; Girard, J.; Pégorier, J.-P. Troglitazone Inhibits Fatty Acid Oxidation and Esterification, and Gluconeogenesis in Isolated Hepatocytes from Starved Rats. Diabetes 1996, 45, 1556-1562. [CrossRef] [PubMed]

100. Aires, C.C.P.; Ijlst, L.; Stet, F.; Prip-Buus, C.; de Almeida, I.T.; Duran, M.; Wanders, R.J.A.; Silva, M.F.B. Inhibition of hepatic carnitine palmitoyl-transferase I (CPT IA) by valproyl-CoA as a possible mechanism of valproate-induced steatosis. Biochem. Pharmacol. 2010, 79, 792-799. [CrossRef] [PubMed]

101. Derks, T.G.J.; van Dijk, T.H.; Grefhorst, A.; Rake, J.-P.; Smit, G.P.A.; Kuipers, F.; Reijngoud, D.-J. Inhibition of mitochondrial fatty acid oxidation in vivo only slightly suppresses gluconeogenesis but enhances clearance of glucose in mice. Hepatology 2008, 47, 1032-1042. [CrossRef] [PubMed]

102. Khungar, V.; Han, S.-H. A Systematic Review of Side Effects of Nucleoside and Nucleotide Drugs Used for Treatment of Chronic Hepatitis B. Curr. Hepat. Rep. 2010, 9, 75-90. [CrossRef] [PubMed]

103. Lee, H.; Hanes, J.; Johnson, K.A. Toxicity of Nucleoside Analogues Used to Treat AIDS and the Selectivity of the Mitochondrial DNA Polymerase. Biochemistry 2003, 42, 14711-14719. [CrossRef] [PubMed]

104. Lewis, W.; Copeland, W.C.; Day, B.J. Mitochondrial dna depletion, oxidative stress, and mutation: Mechanisms of dysfunction from nucleoside reverse transcriptase inhibitors. Lab. Investig. 2001, 81, 777-790. [CrossRef] [PubMed]

105. Moullan, N.; Mouchiroud, L.; Wang, X.; Ryu, D.; Williams, E.G.; Mottis, A.; Jovaisaite, V.; Frochaux, M.V.; Quiros, P.M.; Deplancke, B.; et al. Tetracyclines Disturb Mitochondrial Function across Eukaryotic Models: A Call for Caution in Biomedical Research. Cell Rep. 2015, 10, 1681-1691. [CrossRef] [PubMed]

106. Schultz, J.C.; Adamson, J.S.; Workman, W.W.; Norman, T.D. Fatal Liver Disease after Intravenous Administration of Tetracycline in High Dosage. N. Engl. J. Med. 1963, 269, 999-1004. [CrossRef] [PubMed]

107. Adams, D.H.; Ju, C.; Ramaiah, S.K.; Uetrecht, J.; Jaeschke, H. Mechanisms of Immune-Mediated Liver Injury. Toxicol. Sci. 2010, 115, 307-321. [CrossRef] [PubMed]

108. Holt, M.P.; Cheng, L.; Ju, C. Identification and characterization of infiltrating macrophages in acetaminophen-induced liver injury. J. Leukoc. Biol. 2008, 84, 1410-1421. [CrossRef] [PubMed]

109. Ju, C.; Reilly, T.P.; Bourdi, M.; Radonovich, M.F.; Brady, J.N.; George, J.W.; Pohl, L.R. Protective Role of Kupffer Cells in Acetaminophen-Induced Hepatic Injury in Mice. Chem. Res. Toxicol. 2002, 15, 1504-1513. [CrossRef] [PubMed]

110. Michael, S.L.; Pumford, N.R.; Mayeux, P.R.; Niesman, M.R.; Hinson, J.A. Pretreatment of mice with macrophage inactivators decreases acetaminophen hepatotoxicity and the formation of reactive oxygen and nitrogen species. Hepatology 1999, 30, 186-195. [CrossRef] [PubMed]

111. Mallal, S.; Nolan, D.; Witt, C.; Masel, G.; Martin, A.M.; Moore, C.; Sayer, D.; Castley, A.; Mamotte, C.; Maxwell, D.; et al. Association between presence of HLA-B*5701, HLA-DR7, and HLA-DQ3 and hypersensitivity to HIV-1 reverse-transcriptase inhibitor abacavir. Lancet 2002, 359, 727-732. [CrossRef]

112. Illing, P.T.; Vivian, J.P.; Dudek, N.L.; Kostenko, L.; Chen, Z.; Bharadwaj, M.; Miles, J.J.; Kjer-Nielsen, L.; Gras, S.; Williamson, N.A.; et al. Immune self-reactivity triggered by drug-modified HLA-peptide repertoire. Nature 2012, 486, 554-558. [CrossRef] [PubMed] 
113. Chessman, D.; Kostenko, L.; Lethborg, T.; Purcell, A.W.; Williamson, N.A.; Chen, Z.; Kjer-Nielsen, L.; Mifsud, N.A.; Tait, B.D.; Holdsworth, R.; et al. Human Leukocyte Antigen Class I-Restricted Activation of $\mathrm{CD}^{+}$T-Cells Provides the Immunogenetic Basis of a Systemic Drug Hypersensitivity. Immunity 2008, 28, 822-832. [CrossRef] [PubMed]

114. Batchelor, J.R.; Welsh, K.I.; Tinoco, R.M.; Dollery, C.T.; Hughes, G.R.; Bernstein, R.; Ryan, P.; Naish, P.F.; Aber, G.M.; Bing, R.F.; et al. Hydralazine-induced systemic lupus erythematosus: Influence of HLA-DR and sex on susceptibility. Lancet 1980, 1, 1107-1109. [CrossRef]

115. Dunphy, J.; Oliver, M.; Rands, A.L.; Lovell, C.R.; McHugh, N.J. Antineutrophil cytoplasmic antibodies and HLA class II alleles in minocycline-induced lupus-like syndrome. Br. J. Dermatol. 2000, 142, 461-467. [CrossRef] [PubMed]

116. Chung, W.-H.; Hung, S.-I.; Hong, H.-S.; Hsih, M.-S.; Yang, L.-C.; Ho, H.-C.; Wu, J.-Y.; Chen, Y.-T. Medical genetics: A marker for Stevens-Johnson syndrome. Nature 2004, 428, 486. [CrossRef] [PubMed]

117. Tangamornsuksan, W.; Chaiyakunapruk, N.; Somkrua, R.; Lohitnavy, M.; Tassaneeyakul, W. Relationship Between the HLA-B*1502Allele and Carbamazepine-Induced Stevens-Johnson Syndrome and Toxic Epidermal Necrolysis. JAMA Dermatol. 2013, 149, 1025-1028. [CrossRef] [PubMed]

118. McCormack, M.; Alfirevic, A.; Bourgeois, S.; Farrell, J.J.; Kasperavičiūtè, D.; Carrington, M.; Sills, G.J.; Marson, T.; Jia, X.; de Bakker, P.I.W.; et al. HLA-A*3101 and carbamazepine-induced hypersensitivity reactions in Europeans. N. Engl. J. Med. 2011, 364, 1134-1143. [CrossRef] [PubMed]

119. Ozeki, T.; Mushiroda, T.; Yowang, A.; Takahashi, A.; Kubo, M.; Shirakata, Y.; Ikezawa, Z.; Iijima, M.; Shiohara, T.; Hashimoto, K.; et al. Genome-wide association study identifies HLA-A*3101 allele as a genetic risk factor for carbamazepine-induced cutaneous adverse drug reactions in Japanese population. Hum. Mol. Genet. 2011, 20, 1034-1041. [CrossRef] [PubMed]

120. Locharernkul, C.; Loplumlert, J.; Limotai, C.; Korkij, W.; Desudchit, T.; Tongkobpetch, S.; Kangwanshiratada, O.; Hirankarn, N.; Suphapeetiporn, K.; Shotelersuk, V. Carbamazepine and phenytoin induced Stevens-Johnson syndrome is associated with HLA-B*1502 allele in Thai population. Epilepsia 2008, 49, 2087-2091. [CrossRef] [PubMed]

121. Man, C.B.L.; Kwan, P.; Baum, L.; Yu, E.; Lau, K.M.; Cheng, A.S.H.; Ng, M.H.L. Association between HLA-B*1502 Allele and Antiepileptic Drug-Induced Cutaneous Reactions in Han Chinese. Epilepsia 2007, 48, 1015-1018. [CrossRef] [PubMed]

122. Hung, S.-I.; Chung, W.-H.; Liou, L.-B.; Chu, C.-C.; Lin, M.; Huang, H.-P.; Lin, Y.-L.; Lan, J.-L.; Yang, L.-C.; Hong, H.-S.; et al. HLA-B*5801 allele as a genetic marker for severe cutaneous adverse reactions caused by allopurinol. Proc. Natl. Acad. Sci. USA 2005, 102, 4134-4139. [CrossRef] [PubMed]

123. Lonjou, C.; Borot, N.; Sekula, P.; Ledger, N.; Thomas, L.; Halevy, S.; Naldi, L.; Bouwes-Bavinck, J.-N.; Sidoroff, A.; de Toma, C.; et al. A European study of HLA-B in Stevens-Johnson syndrome and toxic epidermal necrolysis related to five high-risk drugs. Pharmacogenet. Genom. 2008, 18, 99-107. [CrossRef] [PubMed]

124. Kaniwa, N.; Saito, Y.; Aihara, M.; Matsunaga, K.; Tohkin, M.; Kurose, K.; Sawada, J.-I.; Furuya, H.; Takahashi, Y.; Muramatsu, M.; et al. HLA-B locus in Japanese patients with anti-epileptics and allopurinol-related Stevens-Johnson syndrome and toxic epidermal necrolysis. Pharmacogenomics 2008, 9, 1617-1622. [CrossRef] [PubMed]

125. Tassaneeyakul, W.; Jantararoungtong, T.; Chen, P.; Lin, P.-Y.; Tiamkao, S.; Khunarkornsiri, U.; Chucherd, P.; Konyoung, P.; Vannaprasaht, S.; Choonhakarn, C.; et al. Strong association between HLA-B*5801 and allopurinol-induced Stevens-Johnson syndrome and toxic epidermal necrolysis in a Thai population. Pharmacogenet. Genom. 2009, 19, 704-709. [CrossRef] [PubMed]

126. Cornejo Castro, E.M.; Carr, D.F.; Jorgensen, A.L.; Alfirevic, A.; Pirmohamed, M. HLA-allelotype associations with nevirapine-induced hypersensitivity reactions and hepatotoxicity. Pharmacogenet. Genom. 2015, 25, 186-198. [CrossRef] [PubMed] 
127. Carr, D.F.; Chaponda, M.; Jorgensen, A.L.; Castro, E.C.; van Oosterhout, J.J.; Khoo, S.H.; Lalloo, D.G.; Heyderman, R.S.; Alfirevic, A.; Pirmohamed, M. Association of Human Leukocyte Antigen Alleles and Nevirapine Hypersensitivity in a Malawian HIV-Infected Population. Clin. Infect. Dis. 2013, 56, 1330-1339. [CrossRef] [PubMed]

128. Yunis, J.J.; Corzo, D.; Salazar, M.; Lieberman, J.A.; Howard, A.; Yunis, E.J. HLA associations in clozapine-induced agranulocytosis. Blood 1995, 86, 1177-1183. [PubMed]

129. Goldstein, J.I.; Jarskog, L.F.; Hilliard, C.; Alfirevic, A.; Duncan, L.; Fourches, D.; Huang, H.; Lek, M.; Neale, B.M.; Ripke, S.; et al. Clozapine-induced agranulocytosis is associated with rare HLA-DQB1 and HLA-B alleles. Nat. Commun. 2014, 5, 4757. [CrossRef] [PubMed]

130. Daly, A.K.; Donaldson, P.T.; Bhatnagar, P.; Shen, Y.; Pe'er, I.; Floratos, A.; Daly, M.J.; Goldstein, D.B.; John, S.; Nelson, M.R.; et al. HLA-B 5701 genotype is a major determinant of drug-induced liver injury due to flucloxacillin. Nat. Genet. 2009, 41, 816-819. [CrossRef] [PubMed]

131. Kindmark, A.; Jawaid, A.; Harbron, C.G.; Barratt, B.J.; Bengtsson, O.F.; Andersson, T.B.; Carlsson, S.; Cederbrant, K.E.; Gibson, N.J.; Armstrong, M.; et al. Genome-wide pharmacogenetic investigation of a hepatic adverse event without clinical signs of immunopathology suggests an underlying immune pathogenesis. Pharmacogenom. J. 2007, 8, 186-195. [CrossRef] [PubMed]

132. Hautekeete, M.L.; Horsmans, Y.; van Waeyenberge, C.; Demanet, C.; Henrion, J.; Verbist, L.; Brenard, R.; Sempoux, C.; Michielsen, P.P.; Yap, P.; et al. HLA association of amoxicillin-clavulanate-induced hepatitis. Gastroenterology 1999, 117, 1181-1186. [CrossRef]

133. O’Donohue, J.; Oien, K.A.; Donaldson, P.; Underhill, J.; Clare, M.; MacSween, R.M.; Mills, P.R. Co-amoxiclav jaundice: Clinical and histological features and HLA class II association. Gut 2000, 47, 717-720. [CrossRef] [PubMed]

134. Donaldson, P.T.; Daly, A.K.; Henderson, J.; Graham, J.; Pirmohamed, M.; Bernal, W.; Day, C.P.; Aithal, G.P. Human leucocyte antigen class II genotype in susceptibility and resistance to co-amoxiclav-induced liver injury. J. Hepatol. 2010, 53, 1049-1053. [CrossRef] [PubMed]

135. Lucena, M.I.; Molokhia, M.; Shen, Y.; Urban, T.J.; Aithal, G.P.; Andrade, R.J.; Day, C.P.; Cabello, F.R.; Donaldson, P.T.; Stephens, C.L.; et al. Susceptibility to amoxicillin-clavulanate-induced liver injury is influenced by multiple HLA class I and II alleles. Gastroenterology 2011, 141, 338-347. [CrossRef] [PubMed]

136. Singer, J.B.; Lewitzky, S.; Leroy, E.; Yang, F.; Zhao, X.; Klickstein, L.; Wright, T.M.; Meyer, J.; Paulding, C.A. A genome-wide study identifies HLA alleles associated with lumiracoxib-related liver injury. Nat. Genet. 2010, 42, 711-714. [CrossRef] [PubMed]

137. Hirata, K.; Takagi, H.; Yamamoto, M.; Matsumoto, T.; Nishiya, T.; Mori, K.; Shimizu, S.; Masumoto, H.; Okutani, Y. Ticlopidine-induced hepatotoxicity is associated with specific human leukocyte antigen genomic subtypes in Japanese patients: A preliminary case-control study. Pharmacogenom. J. 2007, 8, 29-33. [CrossRef] [PubMed]

138. Hetherington, S.; McGuirk, S.; Powell, G.; Cutrell, A.; Naderer, O.; Spreen, B.; Lafon, S.; Pearce, G.; Steel, H. Hypersensitivity reactions during therapy with the nucleoside reverse transcriptase inhibitor abacavir. Clin. Ther. 2001, 23, 1603-1614. [CrossRef]

139. Mallal, S.; Phillips, E.; Carosi, G.; Molina, J.-M.; Workman, C.; Tomazic, J.; Jägel-Guedes, E.; Rugina, S.; Kozyrev, O.; Cid, J.F.; et al. HLA-B*5701 screening for hypersensitivity to abacavir. N. Engl. J. Med. 2008, 358, 568-579. [CrossRef] [PubMed]

140. Hughes, D.A.; Vilar, F.J.; Ward, C.C.; Alfirevic, A.; Park, B.K.; Pirmohamed, M. Cost-effectiveness analysis of HLA B*5701 genotyping in preventing abacavir hypersensitivity. Pharmacogenetics 2004, 14, 335-342. [CrossRef] [PubMed]

141. Schackman, B.R.; Scott, C.A.; Walensky, R.P.; Losina, E.; Freedberg, K.A.; Sax, P.E. The cost-effectiveness of HLA-B $* 5701$ genetic screening to guide initial antiretroviral therapy for HIV. AIDS 2008, 22, 2025-2033. [CrossRef] [PubMed]

142. Wolf, E.; Blankenburg, M.; Bogner, J.R.; Becker, W.; Gorriahn, D.; Mueller, M.C.; Jaeger, H.; Welte, R.; Baudewig, M.; Walli, R.; et al. Cost Impact of Prospective Hla-B*5701-Screening Prior to Abacavir/Lamivudine Fixed Dose Combination Use in Germany. Eur. J. Med. Res. 2010, 15, 145-151. [CrossRef] [PubMed] 
143. Schoonen, W.M.; Thomas, S.L.; Somers, E.C.; Smeeth, L.; Kim, J.; Evans, S.; Hall, A.J. Do selected drugs increase the risk of lupus? A matched case-control study. Br. J. Clin. Pharmacol. 2010, 70, 588-596. [CrossRef] [PubMed]

144. Moser, K.L.; Kelly, J.A.; Lessard, C.J.; Harley, J.B. Recent insights into the genetic basis of systemic lupus erythematosus. Genes Immun. 2009, 10, 373-379. [CrossRef] [PubMed]

145. Graham, R.R.; Ortmann, W.A.; Langefeld, C.D.; Jawaheer, D.; Selby, S.A.; Rodine, P.R.; Baechler, E.C.; Rohlf, K.E.; Shark, K.B.; Espe, K.J.; et al. Visualizing Human Leukocyte Antigen Class II Risk Haplotypes in Human Systemic Lupus Erythematosus. Am. J. Hum. Genet. 2002, 71, 543-553. [CrossRef] [PubMed]

146. Fernando, M.M.A.; Stevens, C.R.; Sabeti, P.C.; Walsh, E.C.; McWhinnie, A.J.M.; Shah, A.; Green, T.; Rioux, J.D.; Vyse, T.J. Identification of Two Independent Risk Factors for Lupus within the MHC in United Kingdom Families. PLoS Genet. 2007, 3, e192-e113. [CrossRef] [PubMed]

147. International MHC and Autoimmunity Genetics Network; Rioux, J.D.; Goyette, P.; Vyse, T.J.; Hammarström, L.; Fernando, M.M.; Green, T.; de Jager, P.L.; Foisy, S.; Wang, J.; et al. Mapping of multiple susceptibility variants within the MHC region for 7 immune-mediated diseases. Proc. Natl. Acad. Sci. USA 2009, 106, 18680-18685. [PubMed]

148. Barcellos, L.F.; May, S.L.; Ramsay, P.P.; Quach, H.L.; Lane, J.A.; Nititham, J.; Noble, J.A.; Taylor, K.E.; Quach, D.L.; Chung, S.A.; et al. High-density SNP screening of the major histocompatibility complex in systemic lupus erythematosus demonstrates strong evidence for independent susceptibility regions. PLoS Genet. 2009, 5, e1000696. [CrossRef] [PubMed]

149. De Maat, M.M.R.; ter Heine, R.; Mulder, J.W.; Meenhorst, P.L.; Mairuhu, A.T.A.; van Gorp, E.C.M.; Huitema, A.D.R.; Beijnen, J.H. Incidence and risk factors for nevirapine-associated rash. Eur. J. Clin. Pharmacol. 2003, 59, 457-462. [CrossRef] [PubMed]

150. Warren, K.J.; Boxwell, D.E.; Kim, N.Y.; Drolet, B.A. Nevirapine-associated Stevens-Johnson syndrome. Lancet 1998, 351, 567-561. [CrossRef]

151. Alvir, J.M.J.; Lieberman, J.A.; Safferman, A.Z.; Schwimmer, J.L.; Schaaf, J.A. Clozapine-Induced Agranulocytosis-Incidence and Risk Factors in the United States. N. Engl. J. Med. 1993, 329, 162-167. [CrossRef] [PubMed]

152. Phillips, E.J.; Mallal, S.A. HLA-B*5701 and flucloxacillin associated drug-induced liver disease. AIDS 2013, 27, 491-492. [CrossRef] [PubMed]

153. Alfirevic, A.; Pirmohamed, M. predictiveg enetic testing for drug-induced liver injury: Considerations of clinical utility. Clin. Pharmacol. Ther. 2009, 92, 376-380. [CrossRef] [PubMed]

154. Chalasani, N.; Fontana, R.J.; Bonkovsky, H.L.; Watkins, P.B.; Davern, T.; Serrano, J.; Yang, H.; Rochon, J. Causes, Clinical Features, and Outcomes from a Prospective Study of Drug-Induced Liver Injury in the United States. Gastroenterology 2008, 135, 1924-1934. [CrossRef] [PubMed]

155. Stephens, C.; López-Nevot, M.-Á.; Ruiz-Cabello, F.; Ulzurrun, E.; Soriano, G.; Romero-Gómez, M.; Moreno-Casares, A.; Lucena, M.I.; Andrade, R.J. HLA alleles influence the clinical signature of amoxicillin-clavulanate hepatotoxicity. PLoS ONE 2013, 8, e68111-e68117. [CrossRef] [PubMed]

156. Kim, S.-H.; Saide, K.; Farrell, J.; Faulkner, L.; Tailor, A.; Ogese, M.; Daly, A.K.; Pirmohamed, M.; Park, B.K.; Naisbitt, D.J. Characterization of amoxicillin- and clavulanic acid-specific T-cells in patients with amoxicillin-clavulanate-induced liver injury. Hepatology 2015, 62, 887-899. [CrossRef] [PubMed]

157. Farid, N.A.; Kurihara, A.; Wrighton, S.A. Metabolism and disposition of the thienopyridine antiplatelet drugs ticlopidine, clopidogrel, and prasugrel in humans. J. Clin. Pharmacol. 2013, 50, 126-142. [CrossRef] [PubMed]

158. Ariyoshi, N.; Iga, Y.; Hirata, K.; Sato, Y.; Miura, G.; Ishii, I.; Nagamori, S.; Kitada, M. Enhanced susceptibility of HLA-mediated ticlopidine-induced idiosyncratic hepatotoxicity by CYP2B6 polymorphism in Japanese. Drug Metab. Pharmacokinet. 2010, 25, 298-306. [CrossRef] [PubMed]

159. Lee, W.M.; Larrey, D.; Olsson, R.; Lewis, J.H.; Keisu, M.; Auclert, L.; Sheth, S. Hepatic findings in long-term clinical trials of ximelagatran. Drug Saf. 2005, 28, 351-370. [CrossRef] [PubMed]

160. Pentikäinen, P.J.; Neuvonen, P.J.; Jostell, K.G. Pharmacokinetics of Chlormethiazole in healthy-volunteers and patients with cirrhosis of the liver. Eur. J. Clin. Pharmacol. 1980, 17, 275-284. [CrossRef] [PubMed]

161. Neugebauer, G.; Gabor, M.; Reiff, K. Pharmacokinetics and bioavailability of carvedilol in patients with liver cirrhosis. Drugs 1988, 36, 148-154. [CrossRef] 
162. Morgan, D.J.; McLean, A.J. Therapeutic implications of impaired hepatic oxygen diffusion in chronic liver disease. Hepatology 1991, 14, 1280-1282. [CrossRef] [PubMed]

163. Frye, R.F.; Zgheib, N.K.; Matzke, G.R.; Chaves-Gnecco, D.; Rabinovitz, M.; Shaikh, O.S.; Branch, R.A. Liver disease selectively modulates cytochrome P450-mediated metabolism. Clin. Pharmacol. Ther. 2006, 80, 235-245. [CrossRef] [PubMed]

164. Kovarik, J.M.; Sabia, H.D.; Figueiredo, J.; Zimmermann, H.; Reynolds, C.; Dilzer, S.C.; Lasseter, K.; Rordorf, C. Influence of hepatic impairment on everolimus pharmacokinetics: Implications for dose adjustment. Clin. Pharmacol. Ther. 2001, 70, 425-430. [CrossRef]

165. Chalasani, N.; Gorski, J.C.; Patel, N.H.; Hall, S.D.; Galinsky, R.E. Hepatic and intestinal cytochrome P450 3A activity in cirrhosis: Effects of transjugular intrahepatic portosystemic shunts. Hepatology 2001, 34, 1103-1108. [CrossRef] [PubMed]

166. Guengerich, F.P.; Turvy, C.G. Comparison of levels of several human microsomal cytochrome P-450 enzymes and epoxide hydrolase in normal and disease states using immunochemical analysis of surgical liver samples. J. Pharmacol. Exp. Ther. 1991, 256, 1189-1194. [PubMed]

167. George, J.; Murray, M.; Byth, K.; Farrell, G.C. Differential alterations of cytochrome P450 proteins in livers from patients with severe chronic liver disease. Hepatology 1995, 21, 120-128. [PubMed]

168. Shull, H.J.; Wilkinson, G.R.; Johnson, R.; Schenker, S. Normal Disposition of Oxazepam in Acute Viral-Hepatitis and Cirrhosis. Ann. Intern. Med. 1976, 84, 420-425. [CrossRef] [PubMed]

169. Klotz, U.; Antonin, K.H.; Brügel, H.; Bieck, P.R. Disposition of Diazepam and Its Major Metabolite Desmethyldiazepam in Patients with Liver-Disease. Clin. Pharmacol. Ther. 1977, 21, 430-436. [CrossRef] [PubMed]

170. Crotty, B.; Watson, K.; Desmond, P.V.; Mashford, M.L.; Wood, L.J.; Colman, J.; Dudley, F.J. Hepatic Extraction of Morphine Is Impaired in Cirrhosis. Eur. J. Clin. Pharmacol. 1989, 36, 501-506. [CrossRef] [PubMed]

171. Taburet, A.M.; Naveau, S.; Zorza, G.; Colin, J.N.; Delfraissy, J.F.; Chaput, J.C.; Singlas, E. Pharmacokinetics of Zidovudine in Patients with Liver-Cirrhosis. Clin. Pharmacol. Ther. 1990, 47, 731-739. [CrossRef] [PubMed]

172. Marcellin, P.; De Bony, F.; Garret, C.; Altman, C.; Boige, V.; Castelnau, C.; Laurent-Puig, P.; Trinchet, J.C.; Rolan, P.; Chen, C.; et al. Influence of cirrhosis on lamotrigine pharmacokinetics. Br. J. Clin. Pharmacol. 2002, 51, 410-414. [CrossRef]

173. Fisher, C.D.; Lickteig, A.J.; Augustine, L.M.; Ranger-Moore, J.; Jackson, J.P.; Ferguson, S.S.; Cherrington, N.J. Hepatic Cytochrome P450 Enzyme Alterations in Humans with Progressive Stages of Nonalcoholic Fatty Liver Disease. Drug Metab. Dispos. 2009, 37, 2087-2094. [CrossRef] [PubMed]

174. Kolwankar, D.; Vuppalanchi, R.; Ethell, B.; Jones, D.R.; Wrighton, S.A.; Hall, S.D.; Chalasani, N. Association Between Nonalcoholic Hepatic Steatosis and Hepatic Cytochrome P-450 3A Activity. Clin. Gastroenterol. Hepatol. 2007, 5, 388-393. [CrossRef] [PubMed]

175. Orellana, M.; Rodrigo, R.; Varela, N.; Araya, J.; Poniachik, J.; Csendes, A.; Smok, G.; Videla, L.A. Relationship between in vivo chlorzoxazone hydroxylation, hepatic cytochrome P450 2E1 content and liver injury in obese non-alcoholic fatty liver disease patients. Hepatol. Res. 2006, 34, 57-63. [CrossRef] [PubMed]

176. Kohjima, M.; Enjoji, M.; Higuchi, N.; Kato, M.; Kotoh, K.; Yoshimoto, T.; Fujino, T.; Yada, M.; Yada, R.; Harada, N.; et al. Re-evaluation of fatty acid metabolism-related gene expression in nonalcoholic fatty liver disease. Int. J. Mol. Med. 2007, 20, 351-358. [CrossRef] [PubMed]

177. Baker, S.S.; Baker, R.D.; Liu, W.; Nowak, N.J.; Zhu, L. Role of alcohol metabolism in non-alcoholic steatohepatitis. PLoS ONE 2010, 5, e9570. [CrossRef] [PubMed]

178. Chalasani, N.; Gorski, J.C.; Asghar, M.S.; Asghar, A.; Foresman, B.; Hall, S.D.; Crabb, D.W. Hepatic cytochrome P450 2E1 activity in nondiabetic patients with nonalcoholic steatohepatitis. Hepatology 2003, 37, 544-550. [CrossRef] [PubMed]

179. Emery, M.G.; Fisher, J.M.; Chien, J.Y.; Kharasch, E.D.; Dellinger, E.P.; Kowdley, K.V.; Thummel, K.E. CYP2E1 activity before and after weight loss in morbidly obese subjects with nonalcoholic fatty liver disease. Hepatology 2003, 38, 428-435. [CrossRef] [PubMed]

180. Younossi, Z.M.; Baranova, A.; Ziegler, K.; Del Giacco, L.; Schlauch, K.; Born, T.L.; Elariny, H.; Gorreta, F.; VanMeter, A.; Younoszai, A.; et al. A genomic and proteomic study of the spectrum of nonalcoholic fatty liver disease. Hepatology 2005, 42, 665-674. [CrossRef] [PubMed] 
181. Stepanova, M.; Hossain, N.; Afendy, A.; Perry, K.; Goodman, Z.D.; Baranova, A.; Younossi, Z. Hepatic Gene Expression of Caucasian and African-American Patients with Obesity-Related Non-Alcoholic Fatty Liver Disease. Obes. Surg. 2010, 20, 640-650. [CrossRef] [PubMed]

182. Hardwick, R.N.; Fisher, C.D.; Canet, M.J.; Scheffer, G.L.; Cherrington, N.J. Variations in ATP-binding cassette transporter regulation during the progression of human nonalcoholic fatty liver disease. Drug Metab. Dispos. 2011, 39, 2395-2402. [CrossRef] [PubMed]

183. Okushin, K.; Tsutsumi, T.; Enooku, K.; Kado, A.; Fujinaga, H.; Moriya, K.; Yotsuyanagi, H.; Koike, K. P0972: Expressions of bile acid transporters are inversely correlated with NAFLD activity score in the liver of patients with non-alcoholic fatty liver disease. J. Hepatol. 2015, 62, S710. [CrossRef]

184. Canet, M.J.; Merrell, M.D.; Hardwick, R.N.; Bataille, A.M.; Campion, S.N.; Ferreira, D.W.; Xanthakos, S.A.; Manautou, J.E.; A-Kader, H.H.; Erickson, R.P.; et al. Altered regulation of hepatic efflux transporters disrupts acetaminophen disposition in pediatric nonalcoholic steatohepatitis. Drug Metabo. Dispos. 2015, 43, 829-835. [CrossRef] [PubMed]

185. Murphy, S.K.; Yang, H.; Moylan, C.A.; Pang, H.; Dellinger, A.; Abdelmalek, M.F.; Garrett, M.E.; Koch, A.A.; Suzuki, A.; Tillmann, H.L.; et al. Relationship Between Methylome and Transcriptome in Patients With Nonalcoholic Fatty Liver Disease. Gastroenterology 2013, 145, 1076-1087. [CrossRef] [PubMed]

186. Fisel, P.; Schaeffeler, E.; Schwab, M. DNA Methylation of ADME Genes. Clin. Pharmacol. Ther. 2016, 99, 512-527. [CrossRef] [PubMed]

187. Westlind, A.; Löfberg, L.; Tindberg, N.; Andersson, T.B.; Ingelman-Sundberg, M. Interindividual differences in hepatic expression of CYP3A4: Relationship to genetic polymorphism in the $5^{\prime}$-upstream regulatory region. Biochem. Biophys. Res. Commun. 1999, 259, 201-205. [CrossRef] [PubMed]

188. Ozdemir, V.; Kalow, W.; Tang, B.K.; Paterson, A.D.; Walker, S.E.; Endrenyi, L.; Kashuba, A.D. Evaluation of the genetic component of variability in CYP3A4 activity: A repeated drug administration method. Pharmacogenetics 2000, 10, 373-388. [CrossRef] [PubMed]

189. Kacevska, M.; Ivanov, M.; Wyss, A.; Kasela, S.; Milani, L.; Rane, A.; Ingelman-Sundberg, M. DNA methylation dynamics in the hepatic CYP3A4 gene promoter. Biochimie 2012, 94, 2338-2344. [CrossRef] [PubMed]

190. Ivanov, M.; Kals, M.; Kacevska, M.; Barragan, I.; Kasuga, K.; Rane, A.; Metspalu, A.; Milani, L.; Ingelman-Sundberg, M. Ontogeny, distribution and potential roles of 5-hydroxymethylcytosine in human liver function. Genome Biol. 2013, 14, R83. [CrossRef] [PubMed]

191. Ivanov, M.; Kals, M.; Lauschke, V.M.; Barragan, I.; Ewels, P.; Käller, M.; Axelsson, T.; Lehtiö, J.; Milani, L.; Ingelman-Sundberg, M. Single base resolution analysis of 5-hydroxymethylcytosine in 188 human genes: Implications for hepatic gene expression. Nucleic Acids Res. 2016. [CrossRef] [PubMed]

192. Dominguez, A.A.; Lim, W.A.; Qi, L.S. Beyond editing: Repurposing CRISPR-Cas9 for precision genome regulation and interrogation. Nat. Rev. Mol. Cell Biol. 2016, 17, 5-15. [CrossRef] [PubMed]

193. Gómez-Lechón, M.J.; Tolosa, L.; Conde, I.; Donato, M.T. Competency of different cell models to predict human hepatotoxic drugs. Exp. Opin. Drug Metab. Toxicol. 2014, 10, 1553-1568. [CrossRef] [PubMed]

194. Sison-Young, R.L.; Lauschke, V.M.; Johann, E.; Alexandre, E.; Anthérieu, S.; Aerts, H.; Gerets, H.H.J.; Labbe, G.; Hoët, D.; Dorau, M.; et al. A multicenter assessment of single-cell models aligned to standard measures of cell health for prediction of acute hepatotoxicity. Arch. Toxicol. 2016. [CrossRef] [PubMed]

195. Treyer, A.; Müsch, A. Hepatocyte polarity. Compr. Physiol. 2013, 3, 243-287. [PubMed]

196. Engler, A.J.; Sen, S.; Sweeney, H.L.; Discher, D.E. Matrix Elasticity Directs Stem Cell Lineage Specification. Cell 2006, 126, 677-689. [CrossRef] [PubMed]

197. Rowe, C.; Gerrard, D.T.; Jenkins, R.; Berry, A.; Durkin, K.; Sundstrom, L.; Goldring, C.E.; Park, B.K.; Kitteringham, N.R.; Hanley, K.P.; et al. Proteome-wide analyses of human hepatocytes during differentiation and dedifferentiation. Hepatology 2013, 58, 799-809. [CrossRef] [PubMed]

198. Heslop, J.A.; Rowe, C.; Walsh, J.; Sison-Young, R.; Jenkins, R.; Kamalian, L.; Kia, R.; Hay, D.; Jones, R.P.; Malik, H.Z.; et al. Mechanistic evaluation of primary human hepatocyte culture using global proteomic analysis reveals a selective dedifferentiation profile. Arch. Toxicol. 2016. [CrossRef] [PubMed]

199. Lauschke, V.M.; Vorrink, S.U.; Moro, S.M.; Reyazee, F.; Nordling, Å.; Hendriks, D.F.; Bell, C.C.; Sison-Young, R.; Park, B.K.; Goldring, C.E.; et al. Massive rearrangements of cellular miRNA signatures are key drivers of hepatocyte dedifferentiation. Hepatology 2016. [CrossRef] 
200. Lauschke, V.M.; Hendriks, D.F.; Bell, C.C.; Andersson, T.B.; Ingelman-Sundberg, M. Novel 3D culture systems for studies of liver function and assessments of hepatotoxicity of drugs and drug candidates. Chem. Res. Toxicol. 2016. [CrossRef] [PubMed]

201. Tostões, R.M.; Leite, S.B.; Serra, M.; Jensen, J.; Björquist, P.; Carrondo, M.J.T.; Brito, C.; Alves, P.M. Human liver cell spheroids in extended perfusion bioreactor culture for repeated-dose drug testing. Hepatology 2012, 55, 1227-1236. [CrossRef] [PubMed]

202. Messner, S.; Agarkova, I.; Moritz, W.; Kelm, J.M. Multi-cell type human liver microtissues for hepatotoxicity testing. Arch. Toxicol. 2012, 87, 209-213. [CrossRef] [PubMed]

203. Bell, C.C.; Hendriks, D.F.G.; Moro, S.M.L.; Ellis, E.; Walsh, J.; Renblom, A.; Fredriksson-Puigvert, L.; Dankers, A.C.A.; Jacobs, F.; Snoeys, J.; et al. Characterization of primary human hepatocyte spheroids as a model system for drug-induced liver injury, liver function and disease. Sci. Rep. 2016, 6, 25187. [CrossRef] [PubMed]

204. Davidson, M.D.; Ballinger, K.R.; Khetani, S.R. Long-term exposure to abnormal glucose levels alters drug metabolism pathways and insulin sensitivity in primary human hepatocytes. Sci. Rep. 2016, 6, 28178. [CrossRef] [PubMed]

205. Warren, J.D.; Xiong, W.; Bunker, A.M.; Vaughn, C.P.; Furtado, L.V.; Roberts, W.L.; Fang, J.C.; Samowitz, W.S.; Heichman, K.A. Septin 9 methylated DNA is a sensitive and specific blood test for colorectal cancer. BMC Med. 2011, 9, 133. [CrossRef] [PubMed]

206. Baden, J.; Green, G.; Painter, J.; Curtin, K.; Markiewicz, J.; Jones, J.; Astacio, T.; Canning, S.; Quijano, J.; Guinto, W.; et al. Multicenter evaluation of an investigational prostate cancer methylation assay. J. Urol. 2009, 182, 1186-1193. [CrossRef] [PubMed]

207. Waring, M.J.; Arrowsmith, J.; Leach, A.R.; Leeson, P.D.; Mandrell, S.; Owen, R.M.; Pairaudeau, G.; Pennie, W.D.; Pickett, S.D.; Wang, J.; et al. An analysis of the attrition of drug candidates from four major pharmaceutical companies. Nat. Rev. Drug Discov. 2015, 14, 475-486. [CrossRef] [PubMed]

(C) 2016 by the authors; licensee MDPI, Basel, Switzerland. This article is an open access article distributed under the terms and conditions of the Creative Commons Attribution (CC-BY) license (http://creativecommons.org/licenses/by/4.0/). 